\title{
Collaboration in a "Land without a Quisling": Patterns of Cooperation with the Nazi German Occupation Regime in Poland during World War II
}

\author{
Klaus-Peter Friedrich
}

Why has Poland witnessed recurring debates on collaboration with the Nazi German occupation during World War II? In the immediate aftermath of the war, the controversy over efforts of certain individualspoliticians, journalists, actors, and so forth-to cooperate with the German occupiers raged in the Polish press and divided Poland's intellectuals. Some had to appear in court, as, for example, Stanisław Wasylewski, a former collaborator with the Lwów (L'viv) Polish-language newspaper Gazeta Lwowska, edited by the occupying regime's propaganda board from 1941 to 1944. Though acquitted, Wasylewski remained an outcast for his leftist colleagues and could not resume his writing profession.' Forty years later, in 1986, a dispute was sparked by Claude Lanzmann's film Shoah. Polish officials as well as Polish Catholic intellectuals protested against what they perceived as an anti-Polish bias. The French director was charged with constructing a "highly prejudicial image of the primitive Pole," since some of Lanzmann's interviewees did not conceal their anti-Jewish prejudices while recounting memories of their experiences as "bystanders" during the Nazi war against the Polish Jews." In 1987, literary critic Jan Błoński, in his essay "Biedni Polacy patrzą na getto" (translated as "The Poor Poles Look at the Ghetto"), challenged accepted notions about the nature of Polish-Jewish relations during World War II. ${ }^{3}$ Błoński discussed the Poles' sphere of responsibility vis-à-vis the Jewish Holocaust, claiming that the Poles' stance was not beyond reproach. He invited the Poles to admit to the fact that they did not help the persecuted Jews as much as they could have done. In the Catholic sector of the Polish press, there ensued a lively debate that was, however, narrowly limited to

Cordial thanks to John Connelly and the editors of Slavic Review for their helpful remarks during the conception and structuring of this essay-and their enormous commitment to making it sound like real English.

1. Klaus-Peter Friedrich, "Publizistische Kollaboration im sog. Generalgouvernement: Personengeschichtliche Aspekte der deutschen Okkupationsherrschaft in Polen (1939-1945)," Zeitschrift für Ostmilteleuropa-Forschung 48, no. 1 (1999): 50-89, esp. 82-85.

2. Quoted in Hans-Werner Rautenberg, "Ressentiments und Annäherungsversuche: Das polnisch-jüdische Verhältnis in der Publizistik 1987-1992," Dokumentation Ostmitteleuropa 18, nos. 5-6 (December 1992): 22.

3. First published in Tygodnik Pouszechny, no. 2, 11 January 1987. English translation in Polin 2 (1987): 321-36. 
an intellectual milieu. ${ }^{4}$ More recently, Jan Gross's book Neighbors unleashed a national soul-searching and raised a stir in a much wider public, producing a large number of statements in Poland's media (now free from the fetters of the communist state's censorship)..$^{5}$ Most recently, another controversy - this time limited to historians and people involved at the time-arose from charges brought forth against Kraków intellectuals who were busy in a Nazi German "scientific" institution, the Institut für Deutsche Ostarbeit. ${ }^{6}$

These periodically erupting debates seem to challenge a picture of Poland's history that has developed since World War II, namely that Polish society unbendingly resisted the German occupier in complete solidarity. And they are all the more remarkable when one considers the silence of mainstream Polish histories on the subject. Indeed, according to most historians-especially those of the People's Republic - there was no such thing as collaboration. Within Poland those who recite unpopular historical facts are frequently accused of running down their country, while those outside often find themselves confronted with the reproach of "anti-Polonism." Still, discontent with familiar interpretations persists and finds expression in intermittent charges of collaboration. This lingering unease will only be overcome when historians confront and satisfy the need for a "history of collaboration in Poland."

In the present article, I resume some of the arguments I put forward in a lengthy essay dealing with (deficiencies of) Polish historiography on the Nazi German occupation. ${ }^{7}$ But I also draw on other researchers' observations about the complex relationship of Poles, Jews, and Germans from 1939 to $1944-45$ and beyond. ${ }^{8}$ Certain building blocks for a future

4. The most important statements in the debate are collected in Antony Polonsky, ed., "My Brother's Keeper?" Recent Polish Debates on the Holocaust (London, 1990); further Polish statements in German translation in Rautenberg, "Ressentiments," 41-146.

5. See Jan T. Gross, Neighbors: The Destruction of the Jewish Community in Jedwabne, Poland. (Princeton, 2001); important contributions to the discussion in Poland are collected in Antony Polonsky and Joanna B. Michlic, eds., The Neighbors Respond: The Controversy over the Jedwabne Massacre in Poland (Princeton, 2004).

6. See the discussion on the book by Anetta Rybicka, Instytut Niemieckiej Pracy Wschodniej, Institut für Deutsche Ostarbeit, Kraków 1940-1945 (Warsaw, 2002), documented in German translation in Inter Finitimos: Jahrbuch zur deutsch-polnischen Beziehungsgeschichte, 2004, no. 2:51-74; and the statements published in Tygodnik Powszechny in spring and summer 2003.

7. Klaus-Peter Friedrich, "Über den Widerstandsmythos im besetzten Polen in der Historiographie," 1999: Zeitschrift für Sozialgeschichte des 20. und 21. Jahrhunderts 13, no. 1 (1998): 10-60. See also Klaus-Peter Friedrich, "Kollaboration und Antisemitismus in Polen unter deutscher Besatzung (1939-1944/45): $\mathrm{Zu}$ verdrängten Aspekten eines schwierigen deutsch-polnisch-jüdischen Verhältnisses," Zeitschrift für Geschichtswissenschaft 45 , no. 9 (1997): $818-34$.

8. For an overview focusing on the occupied Polish territories, see Michael C. Steinlauf, "Poland," in David S. Wyman, ed., The World Reacts to the Holocaust (Baltimore, 1996), 81-155. On the persistence of the Jewish complex in Polish collective memory, see Michael C. Steinlauf, Bondage to the Dead: Poland and the Memory of the Holocaust (Syracuse, 1997). For an analysis of interethnic relations, see Antony Polonsky, "Beyond Condemnation, Apologetics and Apologies: On the Complexity of Polish Behavior toward the Jews during the Second World War," in Jonathan Frankel, ed., The Fate of the European Jerus, 1939-1945: Continuity or Contingency? (New York, 1997), 190-224; a shorter and more 
"history of collaboration in Poland" already exist. ${ }^{9}$ They are buried in the news material and statements of the wartime underground press, with its worries about the "right" behavior of Poles confronted with the Nazis' projects. They can also be distilled from a certain number of studies on the German occupation of Poland; research on the war years has already produced ample evidence supporting the thesis that various segments of the population were in fact complying, cooperating, and collaborating with the Nazi occupation regime. ${ }^{10}$

Still more is to be learned from the politics of memory applied by the communists, who tolerated for a couple of years a searching debate by Poland's intellectuals. "Immediately after the war-in an atmosphere of a newfound freedom of speech - in the press, in early studies on the economic and social situation under the occupation regime, and in literature, journalists, writers, and scientists touched upon many of the problems that will be dealt with in this article: definition of the "right" behavior of Polish citizens towards the occupiers, the Polish stance towards the Nazi murder of the Jews and the "aryanizations," and the role, in this context, of a homegrown anti-Semitism. Their approach to the complicated everyday life under the occupation was, however, in many cases rather simplistic and increasingly tinged by leftist leanings and stereotyped Marxist concepts of social analysis. ${ }^{12}$ Also, the issue could be raised only in politically one-sided terms - as cooperation with the Germans. Because of this, even the most extreme forms of collaboration with the Soviet occupiers were passed over in silence. ${ }^{13}$ Here I have used all these kinds of sources as well as many Jewish eyewitness accounts.

general treatment is in Antony Polonsky, "Polish-Jewish Relations and the Holocaust," Polin 4 (1989): 226-42.

9. Recently I have dealt with the cooperative functions of welfare institutions like Rada Główna Opiekuńcza and the lower administrative level in the countryside under the occupying regime, as well as with the immediate participation of Poles in anti-Jewish excesses and crimes, which occurred not only in Jedwabne. Klaus-Peter Friedrich, "Zusammenarbeit und Mittäterschaft in Polen 1939-1945," in Christoph Dieckmann, Babette Quinkert, and Tatjana Tönsmeyer, eds., Kooperation und Verbrechen: Formen der "Kollaboration" im östlichen Europa 1939-1945 (Göttingen, 2003), 113-50.

10. This thesis is also put forward in an unbalanced study by Tadeusz Piotrowski, Poland's Holocaust: Ethnic Strife, Collaboration with Occupying Forces and Genocide in the Second Republic, 1918-1947 (Jefferson, N.C., 1998). The author considers collaboration exclusively under ethnic terms as if it was ethnically determined; see my critical review in Zeitschrift für Ostmitteleuropa-Forschung 48, no. 2 (1999): 277-79.

11. A recent contribution to the postwar Polish politics of commemoration is Jonathan Huener, Auschwitz, Poland and the Politics of Commemoration 1945-1979 (Athens, Ohio, 2003).

12. See my study of the communists' official press in postwar Poland: Klaus-Peter Friedrich, "Der nationalsozialistische Judenmord in polnischen Augen: Einstellungen in der polnischen Presse 1942-1946/47" (PhD diss., Universität zu Köln, 2003), 382-528; electronic resource: http://kups.ub.uni-koeln.de/volltexte/2003/952/ (last consulted 6 July 2005); on the press's look back at the murder of the Jews in the immediate postwar period, see also Klaus-Peter Friedrich, "Zweigeteilte Erinnerung: Der Rückblick auf den NS-Judenmord während der kommunistischen Machtübernahme in Polen (1944-1946)," Zeitschrift für Genozidforschung 5, no. 2 (2004): 81-113.

13. See Klaus-Peter Friedrich, "Der 'Fall Józef Mackiewicz' und die polnische Zeitgeschichte: Geschichtsbilder und Biographien zwischen Kollaboration und Widerstand," Zeitschrift für Geschichtsunissenschaft 48, no. 8 (2000): 697-717, esp. 705-6. 
Myths about united Polish resistance were already well established during the occupation. Poles deemed themselves the most uncompromising foes and the most important victims of German expansionism. Pointing to the involvement of Poles in the Nazi occupiers' anti-Jewish crimes proved powerless against such self-perceptions, and at the end of the war, Poles prided themselves, according to journalist Karol Małcużyński, as "the most purely moral among all nations that had to live under [Nazi] occupation." 14

At the same time, the communist regime functionalized the issue by reproaching their political and social adversaries for collaboration. ${ }^{15}$ It started with court trials in which Poles (and Jews) involved in collaboration were sentenced. Soon, however, the judicial cleansing process slowed down due to efforts to win over parts of the communists' former enemies by, for instance, rehabilitating ex-members of the Polish police. Even more momentous in the long run were the consequences of a perfidious propaganda campaign that identified the communists' political and class opponents with former Nazi collaborators-in order to stigmatize them and thus find a pretext to refuse political dialog. ${ }^{16}$

For example, in 1944, communist politician Stefan Jędrychowski was the first head of the propaganda department created by the Polish Committee of National Liberation (PKWN) led by pro-Soviet Poles. He and other propagandists of the communist Polish Workers' Party (PPR) made it clear that the "slogan of the London-based [Polish] government 'Poland - a country without quislings' was false and hypocritical," since on the part of "reactionary" circles a number of offers had been made; meanwhile, the communist groups and their sympathizers alone had allegedly organized armed resistance-against the will of this government and its plenipotentiaries in the country. ${ }^{17}$

In the only noncommunist daily, edited by the Polish Peasant Party, Tadeusz Garczyński considered such an interpretation "the utmost blindness [szczytem zaślepienia]." He reminded readers of the true "size of combat units [sit walczacych] that were active in the occupation period" and confronted the communist travesty with the nationalistic conviction that "the whole people put up a fight, and we will not allow anyone to destroy this praiseworthy aspect of a true national unity in the name of any intrigues whatsoever." According to Garczyński, those who were now disqualifying the "national heroes as instruments of the reaction that had become hopelessly addicted to Nazism do them a dreadful injustice." 18

14. Karol Małcużyński, "Niemiecka propaganda w Generalnej Guberni," Przeglad Socjalistyczny 1, no. 2 (1 December 1945): 34-39.

15. See Klaus-Peter Friedrich, "Die Legitimierung 'Volkspolens' durch den polnischen Opferstatus: Zur kommunistischen Machtübernahme in Polen am Ende des Zweiten Weltkriegs," Zeitschrift für Ostmitteleuropa-Forschung 52, no. 1 (2003): 1-51.

16. See Friedrich, "Legitimierung 'Volkspolens,"” and Friedrich, “'Fall Józef Mackiewicz.'”

17. Stefan Jędrychowski, "22 lipca," Odrodzenie, 1947, no. 29.

18. Gazeta Ludowa, 1947, no. 195. Garczyński was at that time editor-in-chief. It is remarkable that despite censorship, one of the Catholic weeklies was, in 1947, still able to publish the gist of this polemic on (alleged) Polish quislings and collaboration. See "Przegląd prasy: Trzeba świat przekonać," Tygodnik Warszauski, no. 32, 10 August 1947. 
Jędrychowski's statement actually restated earlier assertions published by the communist press..$^{19}$ On the other hand, in his 1946 New Year's address the regime's would-be president Boleslaw Bierut himself proudly took up the patriotic theme, stating that "We had no Quisling-we did not stop resisting." Though Poland was occupied for a long time, "we never had in our country quisling governments and we were, as far as this [issue] is concerned, the only one of the defeated yet unbending countries in Europe [i byliśmy pod tym względem jedynym $\mathrm{z}$ podbitych, ale nieugiętych krajów w Europie]." ${ }^{20}$

By examining cooperation with the Nazi occupying regime on different social levels and in various subgroups of Polish society, I will make clear that the phenomenon was by no means a marginal one. I will first define what I regard as cooperation (or collaboration - the two terms will largely be treated as synonyms) in the Polish context. ${ }^{21}$ Though state collaboration was not a possibility, collaboration was frequently present in contemporary Polish political discussions and existed as a social and ideological phenomenon. I will thus have a look at patterns of collaboration founded on formal, institutionalized cooperation, taking for examples the compulsory Baudienst (labor service) for Polish male youths and the Polish police. There follows a sketch of an ethnically defined group of open collaborators: the so-called Volksdeutsche, or ethnic German population. I then proceed to patterns of informal support of Nazi policies that were often based on a mixture of anti-Semitism and anticommunism and/or expectations to gain materially from the elimination of Jews from Polish economic and social life. Before coming to a conclusion, the last point will turn to the question of "victims as collaborators" by outlining the fate under the Nazi occupation regime of the Polish peasantry and of representatives of the Roman Catholic Church.

\section{Cooperation and Collaboration as a Social Phenomenon}

At first glance it seems difficult to apply to Poland the concept of collaboration used with regard to occupied western Europe. The former leading political elites and powerful social groups of the Polish Second Republic had almost no influence on the fate of their nation, since occupied Poland was turned into an experimental area for repressive and utopian population policies never before seen in Europe. According to Nazi German plans, the Polish nation was to become extinct. Because of a lack of interest on the part of the Nazi leadership, there was no basis for state collaboration. On the contrary, overtures even by Polish fascists and other staunch anti-Semites were rebuffed by the occupiers. ${ }^{22}$ In the western Po-

19. Cf. "Kronika polityczna: Podżegacze wojny bratobójczej," Trybuna Wolności, no. 42, 15 October 1943. 1946.

20. Bolesław Bierut, "Droga przemian dziejowych," Gtos $L u d u$, no. 1 (389), 1 January

21. See the introduction to Dieckmann, Kooperation und Verbrechen, 9-21.

22. See the Warsaw chapter in Tomasz Szarota, $U$ progu zagtady: Zajścia antyzydowskie $i$ pogromy zu okupowanej Europie; Warszawa, Paryz, Amsterdam, Antwerpia, Kowono (Warsaw, 2000); as well as an essay on recent research literature: Klaus-Peter Friedrich, "Juden und 
lish territories that had been annexed to the Reich, Polish state authority was abolished entirely. At the lower administrative level in the so-called Generalgouvernement (GG), however, the occupiers were dependent on Polish cooperation for their social, educational, and cultural policies.

It was Jan Gross who first explored Polish-German interaction under an occupation regime that lasted more than five years. In his inspiring study on the GG published in 1979, a book largely ignored in Polish historiography, he dealt with Polish cooperation with the Germans and considered it a proper background for analyzing a society under duress. ${ }^{23}$ But Gross did not address in this context the Nazi regime's anti-Jewish crimes.

The number of employees in the administration-in the beginning of 1941 much smaller $(122,700)$ than before the war-increased by mid1943 to $206,300,{ }^{24}$ and a year later the pre-1939 level was surpassed by 50 percent. The Polish share of mayors in the GG (excluding Galicia) reached 73 percent. ${ }^{25}$ The occupiers wanted priests but also Polish mayors, heads of the district councils, and representatives of the cooperatives (Spotem) to take part in attracting young Poles to work in the Reich. Even in the annexed areas of western Poland some Polish civil servants were retained by necessity.

In evaluating collaboration in occupied Poland the time factor is crucial. There was fertile ground in the early war years. Willingness to collaborate was much more pronounced in 1939-40 than after the first setbacks of the Wehrmacht. From these years dates a memorandum of a group of Piłsudskists and nationalists sojourning in exile in western Europe who offered to the German Foreign Office political cooperation directed against the Soviet Union. The Auswärtiges Amt did not make use of the offer. ${ }^{26}$

With time, leading representatives of the Polish resistance built authority and decided what kind of cooperation with the occupiers was to be allowed. According to Leszek Gondek's estimates, underground courts dealt with approximately 5,000 cases of collaboration, sentenced 3,500 people to their death, and had 2,500 of them executed. ${ }^{27}$ Czeslaw Madajczyk even gives the number of more than ten thousand persons sen-

jüdisch-polnische Beziehungen in der Zweiten Polnischen Republik (1918-1939): Neuere Literatur," Zeitschrift für Ostmitteleuropa-Forschung 46, no. 4 (1997): 535-60, esp. 555-59.

23. Jan Tomasz Gross, Polish Society under German Occupation: The Generalgouvernement, 1939-1944 (Princeton, 1979), 119; see also Friedrich, "Uber den Widerstandsmythos," 15-16. The district of Galicia has since been the subject of two studies focusing on the persecution of the Jewish population: Dieter Pohl, Nationalsozialistische Judenverfolgung in Ostgalizien 1941-1944 (Munich, 1996), and Thomas Sandkühler, "Endlösung" in Galizien: Der Judenmord in Ostpolen und die Rettungsinitiativen von Berthold Beitz 1941-1944 (Bonn, 1996).

24. These figures include the city of Warsaw but do not include the districts of Warsaw and Galicia and the employees of the Ostbahn. Wactaw Długoborski, "Die deutsche Besatzungspolitik und die Veränderungen der sozialen Struktur Polens 1939-1945," in Wacław Długoborski, ed., Zweiter Weltkrieg und sozialer Wandel: Achsenmächte und besetzte Länder (Göttingen, 1981), 345; Gross, Polish Society under German Occupation, 133-34.

25. Gross, Polish Society under German Occupation, 141.

26. In July 1940. Bernard Wiaderny, "Nie chciana kolaboracja: Polscy politycy i nazistowskie Niemcy w lipcu 1940," Zeszyty Historyczne, 2002, no. 142:131-40.

27. Leszek Gondek, Polska karczaca 1939-1945 (Warsaw, 1988), 120. 
tenced by Polish underground courts for "inappropriate behavior towards the occupation regime." ${ }^{28}$ The Polish underground press repeatedly condemned the cooperation of actors, journalists, and "renegade" ideological collaborators. ${ }^{29}$ Since denunciations of fellow citizens became a widespread phenomenon, ${ }^{30}$ the Home Army's (AK) underground press exhorted the population to abstain from using the occupying authorities to take revenge on somebody.

Given the limited scope of action available to Polish elites and a most brutal occupation regime from the very beginning, Polish initiatives to find a way to get along with the invader without provoking an excessive number of victims were a significant part of social life, at least in the years prior to Stalingrad. On the basis of anti-Semitism and anti-Sovietism some groups even tried to get along with the occupier, thanks to a common ideological language.

The seemingly clear-cut distinctions between cooperation, collaboration, and resistance have to be attributed to the rapidly changing perspective in the very last years of the war when the defeat of the Wehrmacht was fast approaching. ${ }^{31}$ Those years were characterized by brutally preventive measures against potential enemies, mass shootings of hostages, "pacifications" in the countryside, and, in summer 1944, the ruthless suppression of the Warsaw Uprising. The efforts of advocates of loyal cooperation to work out a modus vivendi with the occupiers degenerated in the eyes of many compatriots and now appeared as treacherous collaboration with a hostile power. As Martin Broszat opines, with Germany's declining fortunes "the moral and political status of those still ready to take on responsibility in view of an emerging military disaster" decreased rapidly. ${ }^{32}$ By that point, cooperation was possible only under an imminent Soviet communist threat, militarily in the region around the eastern Polish town of Nowogródek or in the fight against the Ukrainian Insurgent Army (UPA) in Galicia - as well as on a political and ideological level with the editors of the monthly Przetom (The breakthrough): Jan Emil Skiwski, Dr. Feliks Burdecki, and Jerzy de Nis(s)au, who in 1944 supported the idea of a Polish-German community of interests in view of a common Soviet

28. Czesław Madajczyk, "Kann man in Polen 1939-1945 von Kollaboration sprechen?" in Werner Röhr, ed., Okkupation und Kollaboration 1938-1945: Beiträge zu Konzepten und Praxis der Kollaboration in der deutschen Okhupationspolitik (Berlin, 1994), 148.

29. For an analysis of the underground press see Friedrich, "Nationalsozialistische Judenmord in polnischen Augen," 7-8, 10-11, 15, and the introductions to the chapters of part III; as to the cultural collaboration of Polish artists and intellectuals with both occupation regimes, see Janina Hera, Edward Krasiński, Andrzej Krzysztof Kunert, Tomasz Strzembosz, and Jacek Trznadel, "Kolaboracja-bojkot-weryfikacja: Dyskusja redakcyjna," Pamiętnik Teatralny 46, nos. 1-4 (1997): 4-35, esp. 5, 9-10, 31; see also Friedrich, "Fall Józef Mackiewicz." "

30. See Barbara Engelking, "Szanowny panie gislapo": Donosy do wtadz niemieckich w Warszawie i okolicach w latach 1940-1941 (Warsaw, 2003).

31. Hans Lemberg, "Kollaboration in Europa mit dem Dritten Reich um das Jahr 1941," in Martin K. Bachstein and Karl Bosl, eds., Das Jahr 1941 in der europäischen Politik (Munich, 1972), 143-62, esp. 154.

32. Martin Broszat, "Faschismus und Kollaboration in Ostmitteleuropa zwischen den Weltkriegen," Vierteljahrshefte für Zeitgeschichte 14, no. 3 (1966): 250. 
enemy. ${ }^{33}$ Cooperation was established, too, between German authorities and Polish resistance groups in the persecution of communists and Jews in the Radom district. ${ }^{34}$ Parts of the radically right-wing Narodowe Sily Zbrojne (National Armed Forces) operating there left the country together with the retreating Wehrmacht units.

Some of these goings-on were also known to the average person who had nothing to do with the resistance movement. One Jewish woman who lived under a false identity in a Warsaw cloister in 1943-44 was told the following news by a Polish acquaintance: "Alicja, do you know what our partisans do ... ? When they succeed in catching a group of Jews-and once they seized almost four hundred, in the quarries near Busko-they turn them over to the Germans. A partisan steps out of the forest, a German officer goes to meet him. The group is denounced. The officer salutes, and the partisan salutes and goes back to the forest. ... Alicja, they say that there are one hundred thousand Jews hiding in Warsaw. When the war is over, they will come out of their hiding places and do in the Poles." 35

The Nazi occupation tended to confirm the traditional anti-German convictions of the anticommunist right. Polish resistance groups were therefore almost unanimously hostile toward the Germans, whereas they fiercely dissented in their attitudes towards the Soviets. In a Poland partitioned between two ideologically conflicting powers, it was only natural that accusations of "quislingism" were quickly functionalized in the political and propaganda struggle. ${ }^{36}$

Generally speaking, during the war the Polish underground press was increasingly fond of taking credit for the fact that there was no homegrown counterpart of Vidkun Quisling or Emil Hácha. In the last issue

33. See Friedrich, "Publizistische Kollaboration im sog. Generalgouvernement," 70-75; Friedrich, "Die deutsche polnischsprachige Presse im Generalgouvernement (1939-1945): NS-Propaganda für die polnische Bevölkerung," Publizistik 46, no. 2 (2001): 162-88, esp. 180-81; Małcużyński, "Niemiecka propaganda," 37-38. As regards the vast anti-Soviet cum anti-Semitic propaganda campaign linked to the effort to enlist active Polish collaboration in the last year of the war, see also Friedrich, "Über den Widerstandsmythos," 50-52.

34. Lucjan Dobroszycki and Marek Getter, "The Gestapo and the Polish Resistance Movement," Acta Poloniae Historica 4 (1961): 85-118, esp. 105; see also Wlodzimierz Borodziej, Terror und Politik: Die deutsche Polizei und die polnische Widerstandsbezvegung im Generalgouvernement 1939-1944 (Mainz, 1999); Polish edition: Terror i polityka: Policja niemiecka a polski mech oporu w GG 1939-1944 (Warsaw, 1985).

35. Quoted in Helena Szereszewska, Krzyz $i$ mezuza (Warsaw, 1993), 394; English edition: Memoirs from Occupied Warsaw 1940-1945 (London, 1997). Shortly after the war, Michal Borwicz hinted at the fact that the readiness and wish to believe in misdeeds and murder plans of "the Jews" was part of a Polish cultural code at that time. Even after the Holocaust had raged next to them, susceptible Poles were afraid of the mythically raised power of "the Jews." Michał M. Borwicz, Organizowuanie wuściektości (Warsaw, 1947), 33, 45,49 .

36. See Klaus-Peter Friedrich, "Polen und seine Feinde (sowie deren Kollaborateure): Vorwürfe wegen 'polnischer Kollaboration' und 'jüdischer Kollaboration' in der polnischen Presse (1942-1944/45)," in Joachim Tauber, ed., "Kollaboration" in Nordosteuropa in der ersten Hälfte des 20. Jahrhunderts: Erscheinungsformen - Rezeption - Geschichtspolitik (Wiesbaden, 2006). 
of the Home Army organ, Biuletyn Informacyjny, the editors resumed the theme, stating: "Poland is an organically anti-Fascist country. In our country there is no Hacha, Quisling [or] Vlasov [and] no pro-Fascist party." ${ }^{37}$ Already in 1943 the Catholic resistance organ Kultura Jutra commented that Poles had developed an inferiority complex, compensated time and again by pathetic affirmations like "Polska pierwsza stawila opór" (Poland first resisted), "Polska nie wydała Quislinga" (Poland didn't bring forth a Quisling); in reality - the underground paper opined - the Polish contribution to the war against Nazi Germany was small despite a disproportionately high number of casualties. ${ }^{38}$

By contrast, the daily newspaper of the pro-Soviet Polska Partia Socjalistyczna (PPS), Robotnik, announced five weeks before the end of the war: "It is to be credited to our healthy instinct of Polishness that during the occupation period there was no organized political center that was so daring as to initiate 'cooperation' with the Germans and that-in spite of the siren songs of German propaganda - no Polish Quisling, Degrelle, or Laval appeared on the scene. ... Also in our country the occupation has left behind a great deal of dirt and rubbish uniting all the enemies of the new order in closed ranks." Among the "dirt and rubbish" Robotnik recognized "the beneficiaries of former Jewish property and quite simply swindlers and profiteers of diverse caliber." The PPS's newspaper claimed "the poisonous weeds have to be pulled out of Polish soil and completely destroyed." ${ }^{9}$

\section{Institutionalized Cooperation with the German Occupiers}

Since the 1970s, a number of studies have appeared in Poland that portray institutions active during the war years - though the authors have avoided looking at the topic from the perspective of Polish cooperation with the occupation regime. The first was, in 1977, Bogdan Kroll's study on welfare committees in occupied Warsaw, followed in 1985 by his portrayal of the Main Welfare Council (Rada Glówna Opiekuńcza, RGO), the most important Polish organization that came into being in the GG.40 RGO emerged in order to coordinate the activities of relief action committees. Its most important task was to distribute relief funds and gifts from abroad. RGO and its regional and local branches had to cooperate with the German occupiers administratively. On official occasions, where relations with the Polish population were concerned, leaders of RGO took part as Polish representatives. In spite of their willingness to accept this

37. "Wolność," Biuletyn Informacyjny, no. 3 (317), 19 January 1945.

38. "Niemcy a Polska," Kultura Jutra, no. 10, October 1943.

39. "Czujność-cnotą demokracji," Robotnik, no. 79 (109), 3 April 1945.

40. Bogdan Kroll, Opieka $i$ samopomoc spoteczna iv Warszawie 1939-1945 (Warsaw, 1977). Bogdan Kroll, Rada Gtótuna Opiekuñcza, 1939-1945 (Warsaw, 1985). In contemporary German documents, RGO is called "Polnischer HauptausschuB" or "Haupthilfeausschuß"-in September 1944 semantically enhanced to the status of a "Polnischer Nationalausschuß." 
state of affairs, tensions arose time and again due to an exceptionally brutal occupation policy. ${ }^{41}$

In 1983, Mścisław Wróblewski published the first in-depth treatise on the so-called Baudienst, which was institutionalized in the Kraków district of the GG in May 1940 on the initiative of General Governor Hans Frank, in cooperation with the Reichsarbeitsdienstführer Heinrich Hinkel. ${ }^{42}$ The Baudienst quickly spread to other districts. ${ }^{43}$ Beyond strengthening the Nazified education and discipline of the younger generation through "hard labor," the organization also pursued economic and politically propagandistic aims. The Baudienst was made up of eighteen- to twentythree-year-old Polish and Ukrainian draftees who were kept in barracks under the command of German officers, paid "pocket-money," and made to labor in public works. In Kraków, for instance, 1,100 young Polish men were active in restoring houses and streets damaged during the German attack on Poland in September 1939.44

According to the numbers given by Wróblewski, the Baudienst youth's involvement in the occupying regime's projects was by no means marginal. In mid-1941 the Baudienst comprised no more than seven thousand men, but by the spring of 1944 it had grown to its peak membership of approximately forty-five thousand. ${ }^{45}$ Thus, the labor service was the biggest youth organization in the GG. ${ }^{46}$ Only in the second half of 1944 did the numbers rapidly decline.

Towards the end of the war, the cheap labor reserve gained importance in the buildup of defense positions in the GG. ${ }^{47}$ Service in the Baudienst lasted seven months (vacations included) ${ }^{48}$ It was a prerequisite for further education in a technical college ${ }^{49}$ Yet a certain portion of the conscripts, Wróblewski explains, had always tried to elude service, and after April 1942 they could be punished with death. Escapees from the Bau-

41. For a closer look at collaborationist aspects of RGO's activities, see Friedrich, "Zusammenarbeit und Mittäterschaft," 126-30.

42. Mścisław Wróblewski, Stużba budowlana (Baudienst) w Generalnym Gubernatorstwie, 1940-1945 (Warsaw, 1984).

43. The northeast along with the Warsaw district and parts of the Lublin and Radom districts were excluded. See Krzysztof Dunin-Wąsowicz, "Przedmowa," in Wróblewski, Stuziba budowlana, 7; and the map entitled "Übersichtskarte der territorialen Gliederung," in the same volume, 48. According to an announcement in the Home Army organ Biuletyn Informacyjny, Baudienst service was extended to the Warsaw district in 1944. Biuletyn Informacyjny, no. 4 (211), 27 January 1944.

44. Czesław Madajczyk, Polityka III Rzeszy w okupowanej Polsce, 2 vols. (Warsaw, 1970), $1: 345,651$. See also [Heinrich] Hinkel, "Der Baudienst," in Max Freiherr du Prel, ed., Das Generalgouvernement (Würzburg, 1942), 69-74.

45. Wróblewski, Stużba budowlana, 13, 40, 44; pages 41-43 include a more precise breakdown of the data.

46. Ibid., 9-10, 30-31.

47. Biuletyn Informacyjny, no. 23 (230), 8 June 1944.

48. Wróblewski, Stuiba budowlana, 11, 13, 45.

49. Madajczyk, Polityka III Rzeszy, 2:151. At the same time, school education for Poles was in general restricted to the primary school level; see Hans-Christian Harten, DeKulturation und Germanisierung: Die nationalsozialistische Rassen- und Erziehungspolitik in Polen 1939-1945 (Frankfurt, 1996); and Georg Hansen, ed., Schulpolitik als Volkstumspolitik: Quellen zur Schulpolitik der Besatzer in Polen 1939-1945 (Münster, 1994). 
dienst camps had to reckon with the possibility of their families becoming targets of reprisals. ${ }^{50}$ Biuletyn Informacyjny, in the beginning of 1944, reported "unbearable conditions" in the Baudienst where "severe penalties and corporal punishment are the order of the day" and appealed to Polish young men "to evade this service for the enemy by all means." 51

Polish firemen, volunteers of "Organisation Todt" who were usually engaged in construction work, and Baudienst conscripts or junacy (as they were often called in Polish) took part in anti-Jewish crimes as auxiliary staff. ${ }^{52}$ In winter 1943, Biuletyn Informacyjny called the Baudienst an "institution of physical and moral destruction"-but abstained from mentioning its function in the Nazis' war against the Jews. ${ }^{53}$ In documents and eyewitness reports, however, they are mentioned as accessories to crimes. In June 1942, "an unknown number of Poles from the Baudienst" supported SS, German, and Polish police in a vast operation (Aktion) against forty thousand Jews who had been compelled to reside in the southern Polish town of Tarnów. ${ }^{54} \mathrm{Junacy}$ dug up graves where Jewish victims of massacres were buried (for example, in Sambor), ${ }^{55}$ they closed off the Jewish quarter in order to keep inmates from fleeing, and they took part in deportations; sometimes the Poles had to search houses and apartments after their Jewish inhabitants had been deported. Dutifully, they dragged those who were hiding out of sheds and crawlspaces and collected the Jews' belongings. ${ }^{56}$

Euphemistically, this kind of Baudienst activity appears in the sources as "Judeneinsatz" and "work in the Jewish quarter"; according to Wróblewski, such "relief action" was rewarded with a daily allowance of seven zloty. ${ }^{57}$ Apart from this pocket money, the young men were invited afterwards to dinner in a nearby restaurant where vodka was lavishly served. Alcoholic drinks and cigarettes were already handed out before and during "work." In spite of this, some of the junacy were unable to bear the strains

50. Wróblewski, Stużba budowlana, 60, 13.

51. Biuletyn Informacyjny, no. 4 (211), 27 January 1944 (emphasis in the original).

52. See the news organ of the representation of the London-based Polish government in the country (Delegatura Rzadu na Kraj), Kraj, no. 15, 2 December 1943, mentioning the misuse of firemen in Siedlce; see also Emanuel Ringelblum, Hersz Wasser, and Eliahu Gutkowski, "Die Hölle der polnischen Juden unter der Hitler-Okkupation: Rapport von Oneg Szabat," in Ruta Sakowska, Die zzueite Elappe ist der Tod: NS-Ausrottungspolitik gegen die polnischen Juden, gesehen mit den Augen der Opfer; Ein historischer Essay und ausgezuählte Dokumente aus dem Ringelblum-Archiv 1941-1943 (Berlin, 1993), 217; Polish edition: Drva etapy: Hitlerowska polityka eksterminacji Zydów w oczach ofiar (Wrocław, 1986); and, as regards Organisation Todt, an anonymous report on the murder of the Jews in the GG sent to the Breslau archbishop cardinal Adolf Bertram, published in Akten der deutschen Bischöfe über die Lage der Kirche 1933-1945, vol. 6 (Mainz, 1985), 210-15.

53. Biuletyn Informacyjny, no. 9, 4 March 1943.

54. Christopher R. Browning, "Beyond Warsaw and Lódz: Perpetrating the Holocaust in Poland," in James S. Pacy and Alan P. Wertheimer, eds., Perspectives on the Holocaust: Essays in Honor of Raul Hilberg (Boulder, 1995), 81.

55. Artur Sandauer, Bytem (Warsaw 1991), 71.

56. Wróblewski, Stużba budowlana, 158-60. According to Leon Najberg's report, in April 1943 junacy participated in the destruction of the quarter of Warsaw where Jews had previously been forced to move. Leon Najberg, Ostatni poustańcy getla (Warsaw 1993), 44.

57. Wróblewski, Stużba budowlana, 158-59. 
physically or mentally and obtained exemptions. ${ }^{58}$ On 2 November 1942, the archbishop of Kraków, Adam Sapieha, asked General Governor Frank to mitigate the (anti-Polish) terror, mentioning "such an appalling and morbid phenomenon as the use of Baudienst youngsters made drunk for the purpose of liquidating.Jews." ${ }^{59}$

Before they were taken to an anti-Jewish operation, the junacy received a sort of training: they were shown pictures of Jews that conformed to Nazi ideology, and "the Jew" was presented to them as vermin. ${ }^{60}$ To this day it is not clear in how many operations the junacy took part and how large the number was of those who actually participated. Due to the rather short service duty and presuming that only local Baudienst units were employed in case of need for supplementary manpower, I would guess that no one was involved in anti-Jewish crimes over a longer period. The question of the extent to which these young helpers of the Nazi German murderers were "ordinary men," though, has so far not been investigated.

In a 1990 study on the Polish Police (PP) - the "policja granatowa" in dark blue uniforms-Adam Hempel inquired into one of the most important Polish institutions that was kept by the Germans. ${ }^{61}$ During the occupation, the PP mainly had to deal with keeping "law and order." Its size increased steadily from the end of 1939: in 1942 its forces numbered 11,500 , and in 1943 about $16,000 .{ }^{62}$ These Polish policemen carried firearms. They could not advance into higher posts comparable to those that existed in occupied western Europe; stations of the PP were directly subject to the German police.

In the eyes of Polish resistance groups, the policemen were henchmen of the occupation authorities. Indeed, their main task was to discipline and control the Polish population. Some of them became targets of assassinations. For example, in May 1943 leaders of the Kierownictwo Walki Cywilnej, the main organ of the "underground state" that combated the

58. In his memoirs, Ludwik Hirszfeld tells us that he had heard about a junak who had "gotten a bullet into his head because he did not want to go along with that." Ludwik Hirszfeld, Historia jednego zycia, 2d ed. (Warsaw, 1957), 349-50. English edition: Hanna Hirszfeldowa, ed., The History of One Life (Fort Knox, Kentucky, n.d.). See also Wróblewski, Stuzba budowlana, 161.

59. Dariusz Libionka, "Die Kirche in Polen und der Mord an den Juden im Licht der polnischen Publizistik und Historiographie nach 1945," Zeitschrift für OstmitteleuropaForschung 51, no. 2 (2002): 207; see also Franciszek Stopniak, "Katolickie duchowieństwo w Polsce i Żydzi w okresie niemieckiej okupacji," in Krzysztof Dunin-Wạsowicz, ed., Spoteczeñstzo polskie wobec martyrologii i walki Żydôw w latach II wojny śziatowej (Warsaw, 1996), $19-42$.

60. Hirszfeld, Historia jednego zycia, 349.

61. Adam Hempel, Pogrobowcy kleski: Rzecz o policii "granatowej" w Generalnym Gubernatorstzie, 1939-1945 (Warsaw, 1990). Hempel actually finished his thesis in 1983, but publication was postponed until after the abolition of state censorship.

62. Compare with the number of green uniformed German Ordnungspolizei in the GG, which consisted, including the Schutzpolizei in bigger cities and the Gendarmerie in the countryside, of twelve to fifteen thousand men; besides there were two thousand functionaries of the German Sicherheitspolizei, supported by three thousand Poles. Browning, "Beyond Warsaw and Lódz," 80. 
spread of collaboration, ${ }^{63}$ made public a list of thirty-eight policemen sentenced for unacceptable behavior. ${ }^{64}$ A contemporary observer noted: "Nobody should dare to call this a Polish police. .. . The dark blue rabble who take bribes wherever they can, utter threats, and commit extortions, who stand to attention in front of every German . . . are not worthy of any justification whatsoever." 65

Like members of the Bahnschutz (railway order service), Polish police checked the luggage of travelers, and they conducted house searches. ${ }^{66}$ Carrying out the occupiers' ordinances, they intervened against the black market, which had become, given the difficult living conditions, an important source of income for many Poles. Later they took part in fighting partisans. Polish policemen were also esteemed by German superiors for their usefulness in anti-Jewish operations. ${ }^{67}$

The main focus of PP activity lay in Warsaw and surrounding areas. ${ }^{68}$ Selected policemen from the province of Pomorze/West Prussia worked in the Warsaw Ghetto; ${ }^{69}$ others patrolled the walls around the Jewish quarter, and during the Jewish uprising in 1943 they helped seal it. On the "Aryan side," Polish police tracked down Jewish refugees and enriched themselves by extortion and bribery. Hempel acknowledges that the occupiers' anti-Jewish propaganda had "certain consequences"-but only with "the most primitive element and the criminals." 70 The sources and reports former Polish policemen Hempel relies on, however, are not compared and confronted with Jewish ones in the archives of, for example, the Warsaw Jewish Historical Institute or the Israel Holocaust memorial Yad Vashem. That is why Hempel's description does not correlate with denouncements of the PP by Jewish eyewitnesses who blame them for eagerly participating in the so-called evacuations from the "ghettos."

In any case, Polish policemen were active in the expulsion and deportation of Jews, for example as a part of "ad hoc armies of ghetto-clearers"

63. The Kierownictwo Walki Cywilnej (Department of Civilian Struggle), part of the so-called underground state, was founded in December 1942 and headed by Stefan Korboński.

64. Richard Lukas, The Forgotten Holocaust: The Poles under German Occupation 19391944 (Lexington, 1986), 118.

65. Arcylojalni urzędnicy (brochure of 1942), quoted in Tomasz Szarota, Okupowanej Warszatuy dzien powszedni: Studium historyczne (Warsaw, 1973); see also the shortened German translation: Warschau unter dem Hakenkreuz: Leben und Alltag im besetzten Warschau 1.10.1939 bis 31.7.1944 (Paderborn, 1985), 515.

66. Hugo Steinhaus, Wspomnienia i zapiski, ed. Aleksandra Zgorzelska (London, 1992), 242, 257.

67. On the similar role of the Schutzmannschaften recruited out of the local Ukrainian, Belarusan, and Polish population in the Polish territories annexed by the Soviet Union in 1939 and then occupied by the Wehrmacht in 1941, see Martin Dean, Collaboration in the Holocaust: Crimes of the Local Police in Belorussia and Ukraine, 1941-1944 (New York, 2000).

68. Marek Getter, "Policja granatowa w Warszawie 1939-1944," in Studia Warszaruskie, vol. 10, Warszawa lat wojny $i$ okupacji, 1939-1944, no. 2 (Warsaw, 1972), 213-37.

69. Joseph Kermish, ed., To Live with Honor and Die with Honor: Selected Documents from the Warsaw Ghetto Underground Archives "O. S." (Oneg Shabbath) (Jerusalem, 1986), 147.

70. Hempel, Pogrobowcy kleski, 168-69. 
in the Lublin region; in Częstochowa, where fifty thousand people were crammed into a small Jewish quarter, Polish policemen guarded entrances and formed about a quarter of the thousand perpetrators in a vast, murderous anti-Jewish operation in June 1942. ${ }^{71}$ As Shmuel Krakowski explains, "In carrying out these tasks the Polish police demonstrated their complete devotion to the Nazi authorities, apart from a few policemen who gave assistance to the Jews." 72 According to a scientist hiding in the south of Poland, Polish policemen were notorious for "dreadfully beating [Jews] who had been packed into loading docks, and for dragging them from attics, tracking them into cellars and sheds and bringing them to the Germans." 73 Bohdan Skaradziński has described the policemen's "sinister role" in the martyrdom of Polish Jews as a "shameful spot on the occupation period," for having provided "a sycophantic, a hangman's assistance." 74

The communist regime liquidated the state police as early as August 1944. To justify this measure, it explained that the policemen had made themselves hated by the whole population; now the PP was replaced by the civil militia (Milicja Obywatelska). ${ }^{75}$ This did not hinder the regime from trying to "verify" former policemen in order to find out who was honest and upright and thus would qualify for rehabilitation - and further usefulness for posts in the new militia. ${ }^{76}$

\section{Open Collaborators: The So-Called Ethnic German Population (Volksdeutsche)}

Historiography has been incapable of describing the complex role of real, alleged, and would-be ethnic Germans under the Nazi regime. ${ }^{77}$ Before

71. Browning, "Beyond Warsaw and Lódz," 87, 82. In local studies, the participation of Polish compatriots was passed over in silence. Cf. Jan Pietrzykowski, Hitlerowcy w Czestochowie w latach 1939-1945 (Poznań, 1959), 166-96. The author dates a "Probe-Selektion" to the beginning of July and the brutal deportations from the Jewish quarter by German police and their-allegedly exclusively_Ukrainian and Latvian auxiliaries to the period from 22 September to 6 October 1942.

72. Shmuel Krakowski, "Polnische Polizei," in Israel Gutman, ed., Encyclopedia of the Holocaust, 4 vols. (New York, 1990), 3:1179. For a similar assessment on the part of a Polish historian, cf. Czesław Madajczyk, Faszyzm i okupacje, 1938-1945: Wykonanie okupacji przez państwa Osi w Europie, 2 vols. (Warsaw, 1983-1984), 2:365.

73. Steinhaus, Wspomnienia, 246. Hugo Steinhaus, formerly a professor of mathematics at Lwów university, was persecuted in 1941 by the Nazi occupying regime as a Jew but went into hiding.

74. Bohdan Skaradziński, "W czasach wojny na prowincji," Więz 21, no. 1 (1978): 87100; no. 2:97. Historian Marian M. Drozdowski sums up: "The dark blue police, part of whose functionaries were in touch with the Home Army, in many cases behaved shamefully towards Jews by actively participating in their liquidation." Marian M. Drozdowski, "Refleksje o stosunkach polsko-żydowskich w czasie drugiej wojny światowej," Kivartalnik Historyczny 97, nos. 3-4 (1990): 182.

75. Rzeczpospolita, no. 16, 18 August 1944.

76. Cf. Rzeczpospolita, no. 191, 18 July 1945.

77. The Lithuanian and Ukrainian ethnic minorities, whose involvement in the Nazi murder of the Jews was conscientiously followed by the Polish underground, cannot be discussed at this point. See Klaus-Peter Friedrich, "Spontane 'Volkspogrome' oder Auswüchse der NS-Vernichtungspolitik? Zur Kontroverse um die Radikalisierung der antijüdischen 
1939, about eight hundred thousand people in the Polish Second Republic regarded themselves as ethnic Germans. During the occupation, this number increased to almost three million. Despite limited research on the subject, one can hazard the following generalization: given their deep distrust of Poles, the Nazi German occupiers expected and depended upon support from the ethnic German minority, whose political loyalty was beyond question. ${ }^{78}$ To the beneficiaries of positive racial discrimination, occupation appeared to be anything but foreign rule. Protestant German adherents of deutsch-national views in particular had come to feel themselves a community under siege during the Polish Second Republic. ${ }^{79}$ Those living in the former Prussian territories greeted the return of German rule in their native lands enthusiastically, and many who regarded the establishment of the new regime as a longed-for liberation proved ready to identify fully with the inhumane aims of Adolf Hitler's policy. For example, members of the ethnic German Selbstschutz (militia, under SS leadership) perpetrated numerous massacres against the nonGerman civilian population in the first days of the war. ${ }^{80}$

Polish citizens regarded by the Nazi authorities as (potential) Germans formed one of the pillars of support for the new regime in the occupied territories. ${ }^{81}$ To declare oneself a German was to open paths to potentially breathtaking social and economic ascent. But the policy of Germanization was more contradictory than the campaign for the socalled Deutsche Volksliste (DVL) seems to suggest. This German Nationality List was created in order to divide ethnic Germans (and people to be reGermanized) into four categories that would guide "racial" selection of the population. ${ }^{82}$ In the GG, the tiny ethnic German population was artificially augmented by enrolling people of ethnic German descent who

Gewalt im Sommer 1941," Kwartalnik Historii Zydów / Jewish History Quarterly, 2004, no. 212:587-611, esp. 602-4.

78. No single history exists of the ethnic Germans in east central Europe. This would be a methodologically difficult enterprise since it would necessitate as a prerequisite disentangling the web of often false or fictitious ethnic classifications.

79. Doris L. Bergen, "The Nazi Concept of 'Volksdeutsche' and the Exacerbation of Antisemitism in Eastern Europe, 1939-1945," Journal of Contemporary History 29, no. 4 (1994): 569-82, esp. 575-78.

80. See, for the GG, Jolanta Adamska, "Organizacja Selbstschutz w Generalnym Gubernatorstwie," in Czesław Pilichowski, ed., Zbrodnie i spratucy: Ludobójstzo hitlerowuskie przed sadem ludzkości i historii (Warsaw, 1980), 504-18; for the territories annexed by the Reich: Christian Jansen and Arno Weckbecker, Der "Volksdeutsche Selbstschutz" in Polen 1939/40 (Munich, 1992); Mirosław Krajewski, "Eksterminacja ludności żydowskiej ziemi dobrzyńskiej w latach drugiej wojny światowej (1939-1945)," Biuletyn Żydowskiego Instytutu Historycznego, 1987, no. 141:55-70; Antoni Witkowski, Mordercy z Selbstschutzu (Warsaw, 1986); Jan Sziling, "Ziemia dobrzyńska w latach okupacji hitlerowskiej (1939-1945)," in Mieczysław Wojciechowski, ed., Studia z dziejów ziemi dobrzyńskiej XV-XX wiek (Warsaw, 1987), 157-207, esp. 163-69.

81. Antoni Szymanowski, "Generalgouvernement-uwagi o niemieckiej polityce okupacyjnej," Straznica Zachodnia, 1946, nos. 1-2:19-29.

82. Franz Maßfeller, ed., Deutsches Staatsangehörigkeitsrecht von 1870 bis zur Gegenwart, 2d ed. (Frankfurt, 1955), 244-52; Erich Becker, "Die Deutsche Volksliste als Mittel zur Festigung des deutschen Volkstums in den eingegliederten Ostgebieten," Zeitschrift für Völkerrecht 26, no. 1 (1942): 35-58; Harten, De-Kulturation und Germanisienung, 99-105. 
had once been Polonized and now were supposed to be re-Germanized. Their numbers grew from about 70,000 in 1939 to 111,000 at the end of 1941 and 264,000 at the end of $1943 .{ }^{83}$

Prospective Germans were outfitted with special identity cards-the so-called Volksdeutschenausweis-and found themselves beneficiaries of a host of privileges, from special restaurants and streetcars to parks and sports facilities, all reserved for their exclusive use. They were entitled to an increase in food rations of 30 to 50 percent. ${ }^{84}$ But they were also supposed to relinquish all social contacts-marriages, friendships, and so forth - with Poles. Those who disobeyed had to reckon with punitive action from the German police charged with enforcing "racial" separation. Yet, beyond the reach of the police, business partnerships flourished between representatives of the occupying regime and the Polish population - and helped enliven a thriving black market.

The number of applicants for the Volksdeutschenausweis was much bigger than the number of ethnic Germans who had been registered before the war. Most applications were approved. But it turned out that these new Germans were not really treated as equals of Reich Germans (for example in regard to food rations). They were looked down upon and regarded as opportunistic Konjunkturdeutsche; in Upper Silesia, many were registered as Volksdeutsche on probation, while authorities tried to improve their position-in order to gain as many soldiers for the Wehrmacht as possible. ${ }^{85}$

In view of the central role given to racist conceptions in Nazi ideology, it seems astonishing that the occupation authorities-including those in the SS responsible for Volkstumspolitik (nationality policy)-did not feel tied to a definition of Volksdeutsch. Many Poles managed to get access to privileged circles by hinting at one or the other German ancestor. As Doris Bergen has noted, the contradictions of such nationality policies suggest that for the SS "the existence of people who could be labeled Volksdeutsche was more important than the cultural or racial authenticity of such claims" of Germanness. ${ }^{86}$ Thus the Nazis partly instituted a traditional Germanization based on enforcing on Poles (the Nazi concept of) German culture, the use of the German language, and political criteria. ${ }^{87}$

83. Długoborski, "Deutsche Besatzungspolitik," 321. Harten states that in the GG by August 1943 about one hundred thousand people had asked for their recognition as "Poles of German descent" (Deutschstämmige); sixty-nine thousand were accepted into the Deutsche Volksliste. Harten, De-Kulturation und Germanisienung, 108.

84. Marek Getter, "Srodowisko niemieckie w Warszawie w latach 1939-1944," in Studia Warszawskie, vol. 17, Warszawa lat wojny $i$ okupacji, 1939-1944, no. 3 (Warsaw, 1973): 223-39, esp. 236; Długoborski, "Deutsche Besatzungspolitik," 323.

85. Szarota, Okupowvanej Warszauy dzien powszedni, 448-52; Długoborski, "Deutsche Besatzungspolitik," 336.

86. See Bergen, "Nazi Concept of 'Volksdeutsche," 571, where the author exemplifies this by the handling of a group of people, "discovered" by Einsatzgruppe B near Smolensk, who had lost their former Germanness due to mixed marriages and assimilation to the surrounding population.

87. Cf. Długoborski, "Deutsche Besatzungspolitik," 304, who is of the opinion that the Germans had totally refrained from this policy. Thus, he dismisses the fact that the Nazi regime, by recognizing those who proclaimed adherence to Germanness as Germans, reduced ad absurdum the official ideological and racist conceptions. 
Whereas in the so-called Warthegau (part of the territory annexed to the Reich) racist regulations were rigorous, in other occupied regions it was sufficient to proclaim verbally one's wish to be German. As a result, in the ethnically and culturally mixed territories of eastern Upper Silesia and the province of Pomorze/West Prussia, Poles joined the German Nationality List en masse - though under a certain administrative compulsion. On the one hand the men became liable for military service, but on the other the population was less subject to expulsions. In all of the annexed territories, the number of those recognized as German by descent (deutschstämmig) rose to almost one-third of the total population. ${ }^{88}$

The prospect of laying one's hands upon Jewish property was another incentive to declare oneself an ethnic German. Ethnic Germans-and Poles who managed to be recognized as such-were beneficiaries of "aryanizations." As Jewish survivors recall, greed and profit seeking transformed "people from our town, Poles" into members of the Selbstschutz who "suddenly heard the call of their German blood!" ${ }^{99}$ Prospective Germans tended to support the regime that had bestowed coveted Jewish property upon them..$^{90}$ According to Bergen, those expecting to make use of the Nazis' racist policy to their personal advantage "found the easiest way to prove themselves good Germans was to prove themselves good Nazis." ${ }^{91}$ Lucjan Dobroszycki and Marek Getter have outlined the sinister role played by ethnic Germans in the GG's Radom district: "Employed in all branches of the occupation administrative, economic, and partly police machinery, they were in a way [sic] officially to collaborate with the [Nazi] Security Police." ${ }^{92}$ In a report on the "Polish Jews' hell under the Hitler occupation" written in June 1942 for the secret archive of the Warsaw Ghetto, the authors bitterly condemned the participation of ethnic Germans in genocide: "Volksdeutsche ... have played a shameful role ... in anti-Jewish actions in Poland.... After the military victory of Germany [in Western Poland] Volksdeutsche were installed at the top of the local administration.... They do not have the requisite qualifications and are appointed due to their adherence to the Nazi party." 93

Having in mind this fatal interrelation between, on the one hand, those invited to partake of privileges accorded by the new lords of the land and those, on the other hand, who were victims of racial hatred, we are able to understand why the Jewish report characterizes ethnic Germans as "mostly small traders and peasants, owners of small farms or day laborers who often do not understand a single word of German." ${ }^{94}$ Only one in four members of an "ethnic German" special unit (Sonderdienst) was

88. Harten, De-Kulturation und Germanisiemung, 107; Martin Broszat, Nationalsozialistische Polenpolitik, 1939-1945 (Stuttgart, 1961), 133.

89. Stefania Heilbrunn and Miriam Chaszczewack, Children of Dust and Heaven: A Collective Memoir (Cape Town, 1978), 71; quoted in: Bergen, "Nazi Concept of 'Volksdeutsche," 574.

90. Bergen, "Nazi Concept of 'Volksdeutsche,'” 572.

91. Ibid., 574.

92. Dobroszycki and Getter, "Gestapo and the Polish Resistance Movement," 103.

93. Ringelblum, "Hölle der polnischen Juden," 204-5. Further examples: Bergen, "Nazi Concept of 'Volksdeutsche,", 569-70.

94. Ringelblum, "Hölle der polnischen Juden," 204. 
able to converse in German..$^{95}$ According to an inmate, the Łódź Jewish "ghetto" was guarded "day and night by SS troops, so-called Volksdeutsche. These would-be Germans were in fact crafty anti-Semite Poles and Ukrainians who had betrayed their country and joined the victor." 96

In the GG, victims of the expulsions from western Poland acquired a kind of intermediate position owing to their knowledge of German, and many of them aspired to be registered as ethnic Germans. ${ }^{97}$ It seems that the only ethnic groups barred from becoming Volksdeutsche were Jews and gypsies. ${ }^{98}$

If it is true, as Czesław Madajczyk contends, that 90 percent of the "would-be Germans" stayed in Poland at the end of the war, ${ }^{99}$ this would suggest that they did not expect much harm, let alone the severe judicial prosecution that befell many of them in the immediate aftermath of the war. But in the eyes of former Polish compatriots, the Volksdeutsche were, in times of an excessive nationalism, simply renegades. Their exclusion from Polish society in turn created new opportunities for self-enrichment among those who had come off badly from the first round of distribution of Jewish property. ${ }^{100}$

\section{Anti-Semitism and Anticommunism}

Despite the fact that radical right-wing conceptions and anti-Jewish attitudes spread enormously in the late 1930s, Polish historical research has widely neglected the fact that even before the war many Poles shared with the Nazis a concept of the enemy as communist and Jewish. ${ }^{101}$ The momentous stereotype of Jewish Bolshevism-ziydokomuna - was, according to historian André Gerrits, "the most recent and widely propagated version of the Jewish world conspiracy myth." 102 But not only right-wing radicals considered the Second Republic's national minorities-and espe-

95. Browning, "Beyond Warsaw and Lódz," 80. See also Peter R. Black, "Rehearsal for 'Reinhard'? Odilo Globocnik and the Lublin Selbstschutz," Central European History 25, no. 2 (1992): 204-26.

96. Ray Eichenbaum, Romeks Odyssee: Jugend im Holocaust (Vienna, 1996), 21.

97. Gross, Polish Society under German Occupation, 140.

98. A Posen expert in international law did not find them even worthy for the lower status of "Schutzangehörige," to which the Poles in the annexed territories belonged. Becker, "Deutsche Volksliste," 53.

99. Czesław Madajczyk, “Teufelswerk': Die nationalsozialistische Besatzungspolitik in Polen," in Eva Rommerskirchen, ed., Deutsche und Polen 1945-1995: AnnäherungenZblizenia (Düsseldorf, 1996), 24-39, esp. 33.

100. See Wlodzimierz Borodziej and Hans Lemberg, eds., “Unsere Heimat ist uns ein fremdes Land geworden . . .": Die Deutschen östlich von Oder und Neiße 1945-1950; Dokumente aus polnischen Archiven, 4 vols. (Marburg, 2000-2004), passim.

101. The relevant sources in the archives of the Warsaw Jewish Historical Institute and the documents in Yad Vashem, or even the reports in the memorial books of the destroyed Jewish communities in Poland, have hitherto not been sufficiently analyzed along this line of inquiry.

102. André Gerrits, "Antisemitism and Anti-Communism: The Myth of 'JudeoCommunism' in Eastern Europe," East European Jewish Affairs 25, no. 1 (1995): 54. 
cially the Jews - to be "foreigners in the Polish home." 103 Most nationalists and representatives of the Roman Catholic Church also anticipated a solution to the "Jewish question" in the mass emigration of Polish Jews. In such scenarios, Jews would leave their property behind. Consequently, in the initial phase of the Nazi occupation regime, when Jews were banned from an ever increasing number of professions and the authorities conceived plans for their expulsion and resettlement in Madagascar, the aims of the Nazis and the Polish right-wing radicals did not fundamentally differ.

In the meantime, the intensity of rabble-rousing anti-Semitic propaganda assumed dimensions hitherto unknown. Under Nazi occupation, state propaganda offices made such propaganda omnipresent, spread by leaflets, in the cinema, in the theater, in exhibitions, on posters, in brochures, by mobile loudspeaker vans and public address systems installed in central squares, and, last but not least, in the Polish language press edited by the occupying authorities. ${ }^{104}$ As Lucjan Dobroszycki sums up: "While German propaganda in occupied Poland was on the whole ineffective, there were a few areas in which it found some response. One of them was its anti-Jewish theme." 105

In the immediate postwar period, in a paper of the Polish socialists allied to the communists, Wacław Zawadzki complained that during the years of occupation a new myth had been founded. Accordingly, Poland was the only occupied country where there were no social or political currents willing to cooperate with the (German) occupier. On the contrary, Zawadzki opined that "the Polish reaction" was able to base its collaboration with the Nazis on two factors: "the Jewish question and hatred towards Soviet Russia." The whole prewar right-wing camp "was potentially and psychologically prepared for cooperation with Nazism." ${ }^{106}$ Consequently, the "reaction" approved and applauded Hitler's anti-Jewish program. Zawadzki reminded his readers that in 1942 Szaniec had commented that the Germans deal with this matter "better and more effectively than anyone else could have done it, especially we [Poles]." ${ }^{107}$ According to Zawadzki the Germans would have found many more helpers among the Poles if they had only wanted to. But now a new myth was emerging, "the myth of pure intentions, ideas, and deeds of all groups in Poland under the [German] occupation. These, however, did not exist."108

103. Thus reads the main title of a book by Wlodzimierz Mich, Obcy w polskim domu: Nacjonalistyczne koncepcje rozwiązania problemu mniejszości narodouych, 1918-1939 (Lublin, 1994).

104. See the more extensive discussion by Lars Jockheck, "Nationalsozialistische Pressepropaganda für Deutsche und Polen im Generalgouvernement 1939-1945" (PhD diss., Universităt der Bundeswehr, 2004).

105. Lucjan Dobroszycki, "The Jews in the Polish Clandestine Press, 1939-1945," in Andrzej K. Paluch, ed., The Jews in Poland (Kraków, 1992), 296.

106. Wacław Zawadzki, "Rewizja mitu (Rzecz o quislingizmie polskim)," Przeglad Socjalistyczny 1, no. 2 (1 December 1945): $30,34$.

107. Szaniec, 15 April 1942; quoted in Zawadzki, "Rewizja mitu," 31. The radically right-wing Szaniec was one of the most popular newspapers of the underground press.

108. Zawadzki, "Rewizja mitu," 34. 
The Polish socialist politician Józef Cyrankiewicz relates a case from his own experience. In a report on the little-known blemishes in the alleged common martyrdom of Poles and Jews so often conjured in Poland after 1945, he remarks: In Auschwitz "we met for the first time our own fascistic idiots. One Polish student girl was pleased that 'though dreadful things happened in the camp, at least the Jewish problem was being solved.' One high school student from a family belonging to the 'intelligentsia,' who was an orderly in the hospital, managed to pull a sick Jew out of his bed and beat him-and one year later he worked in the 'political department' tracking down the żydokomuna. One Polish physician, more eager than the doctors of the SS, sent sick Jews to their death." 109 In 1947, in his own look back at his sojourn in the camps, the young Polish poet Tadeusz Borowski elaborated a nonheroic and self-critical current. In a derisive comment on the peculiar Auschwitz remembrances of the renowned Catholic writer Zofia Kossak (published as $Z$ otchtani), ${ }^{10}$ Borowski reproached her for describing camp life in an idealizing and distorted way. Since Kossak had experienced Auschwitz as a privileged prisoner, Borowski compared her memories to the adventures of Alice in Wonderland. ${ }^{111}$

The communist paper Trybuna Wolnosici lamented in early 1944 "the criminal and despicable role" played by Polish policemen who tracked down the remnants of the surviving Jewish population and extorted money from them. ${ }^{112}$ Only sporadically did influential groups of the Polish underground try to counter grave excesses of anti-Jewish collaboration with the Nazis. ${ }^{113}$

Whereas part of the underground press sternly exhorted its readers not to help the Germans in the persecution, robbery, and murder of the Polish Jews, the right saw no reason to stop its anti-Jewish propaganda. ${ }^{114}$ The concept of the "Jewish enemy" persisted undiminished. In 1943, a

109. Józef Cyrankiewicz, "Oświęcim walczący," Naprzód, no. 18, 24 June 1945.

110. Zofia Kossak, Z otchtani: Wspomnienia z lagru (Częstochowa, 1946). On the controversy in the Polish press about Kossak's memoirs, see Friedrich, "Nationalsozialistische Judenmord in polnischen Augen," 597, 599-600; Friedrich, "Zweigeteilte Erinnerung," $96-98$.

111. "Alicja w krainie czarów," Pokolenie, January 1947. See also Paweł Jasienica, "Warto pogadać," Tygodnik Powszechny, no. 9 (102), 2 March 1947, 4; Irena Pannenkowa, "Prawda o pobycie Kossak-Szczuckiej w Oświęcimiu," Tygodnik Warszawuski, no. 1, 4 January 1948,5 ; and, on Borowski's view of the inmates' cooperation with the camp authorities, Tadeusz Borowski, This Way to the Gas, Ladies and Gentlemen (New York, 1976).

112. Trybuna Wolności, no. 50, 20 February 1944. As to the activities of extortionists (szmalcoumicy) who tracked down Jews living in hiding, scholars have recently analyzed important source material. See Anita Sosnowska, "Tak zwani szmalcownicy na przykładzie Warszawy i okolic (1940-1944)," Kwartalnik Historii Zydów / Jewish History Quarterly, 2004, no. 211:359-74; Jan Grabowski, "Szmalcownicy warszawscy, 1939-1942," Zeszyly Historyczne, 2003, no. 143, 85-117.

113. Friedrich, "Kollaboration und Antisemitismus," 833-34.

114. See Friedrich, "Nationalsozialistische Judenmord in polnischen Augen," 23276; and Klaus-Peter Friedrich, "Polnische 'Kollaboration' und jüdische 'Kollaboration': $\mathrm{Zu}$ Einstellungen der polnischen Untergrundpresse 1942-1944/45," Kwartalnik Historii Żydów / Jervish History Quarterly, 2004, no. 210:182-96. 
paper of the radical right-wing National Armed Forces (NSZ) insistently warned against regarding Jews as "fellow brothers" or consenting to their "return into Poland's political and economic life": "we must not do so! We may condemn the Germans for their bestial methods but we must not forget that Jewry was always and will remain a destructive element in our state organism. The liquidation of the Jews in the Polish territories is of great importance for future development because it frees us from a millionheaded parasite." 115

In general, the numerous groups illegally editing leaflets or periodicals did not see the catastrophe of Poland's Jews for what it was. Some of them realized with a peculiar lack of understanding that parts of the Jewish community (Order Service, Judenräte) helped the murderers in organizing deportations to the death camps, while Jews in England and North America allegedly concealed the news of the Nazi annihilation project. ${ }^{116}$ Even papers expressing outrage and compassion otherwise kept to traditional anti-Semitic stereotypes. ${ }^{117}$ One exception on the political right was the anticommunist writer Józef Mackiewicz. "Hitler's terror was dreadful," he wrote looking back on the occupation period, "but with regard to the Poles it never went beyond the degree of terror known from wars of the past... Those who were in Poland at this time remember well that a Jew who succeeded in acquiring documents identifying him as an 'aryan' Pole thought of himself as practically rescued. Thus, there was a gap between the fate of the Poles and the fate of the Jews. With regard to the Poles it was not physical terror, which was the height of Hitler's insane policy - it befell only a certain percentage of the population. It was rather the fact that the whole population was subjected to the insane method of feeling contempt for their dignity." 118 In communist Poland, however, Mackiewicz's voice and his conclusions on Polish-JewishGerman relations, which were far ahead of their time, were not heeded.

\section{"Aryanizations": The Jewish Property Issue}

Polish social history has almost totally neglected the "aryanizations" enforced by the occupying authorities, that is, the takeover of Jewish property by non-Jewish citizens. Comprehensive studies have yet to be attempted on the extent of Polish participation, or the social background, motives, and attitudes of the beneficiaries. Neither have the social and economic consequences of Nazi anti-Jewish policy been discussed in detail. According to Waclaw Długoborski, it is still uncertain "to what extent

115. Sz., "Sprawa bardzo ważna," Barykada, no. 3, March 1943.

116. Friedrich, "Polen und seine Feinde."

117. See Friedrich, "Nationalsozialistische Judenmord in polnischen Augen"; Jan Tomasz Gross, Upiorna dekada: Trzy eseje o stereotypach na temat Zydów, Polakótu, Niemcówu i komunistów, 1939-1948 (Kraków, 1998); Paweł Szapiro, "Prasa konspiracyjna jako źrôdlo do dziejów polsko-żydowskich w latach II wojny šwiatowej-uwagi, pytania, propozycje badawcze," Biuletyn Żydowskiego Instytutu Historycznego, 1988, nos. 147-148: 197-210.

118. Józef Mackiewicz, Sieg der Provokation: Die Phasen der Entwicklung des Kommunismus in Rußland und Polen und die Frage der deutsch-polnischen Beziehungen (Munich, 1964), 144. 
the Polish middle classes profiteered from the takeover of 'non-aryan' businesses." 119 As early as 1945 an infuriated Kazimierz Wyka, who was a renowned literary critic and keen observer of everyday life under the occupation, made the following comparison: "Under the axe of a German executioner guilty of crimes unprecedented in history, the Polish shop owner reached out for the cashbox keys of his Jewish competitor and in the process managed to convince himself that this was the most moral thing in the world. Guilt and crime are with the Germans [but] ours are the keys and the cashbox." 120

In the GG, the Polish population benefited economically from the suppression of the Jews. When the occupying authorities created quarters for "Germans only" and expelled Poles from western Poland, they also created a huge demand for living space. ${ }^{121}$ Those who seized apartments that had belonged to Jews tended to disregard orders of the Polish exile government condemning such behavior, and made clear that they would not surrender formerly Jewish assets. ${ }^{122}$ In 1942 the underground press close to the Home Army complained that "the moral level of the Polish masses is simply dreadful. . . . Cases of mass robbery of former Jewish property bear eloquent witness to the ongoing moral decay." ${ }^{23} \mathrm{On}$ profiteers of the anti-Jewish policy in a small provincial town, the Szczebrzeszyn physician Zygmunt Klukowski noted in his diary on 22 April 1942: "From diverse sides I heard about the scandalous behavior of parts of the Polish population and the robbery of Jewish apartments left behind." ${ }^{24}$ There was a flourishing and lucrative trade with former Jewish property emanating from the "ghettos"-furniture, fur coats, jewelry, and other valuables. ${ }^{125}$ Due to the ousting of Jewish petty traders, many Poles became involved in commerce. According to Wyka, "In the departments and offices everyone traded. The offices themselves were only meeting points ... for profiteering." ${ }^{26}$ In 1945, Wyka opined from his own everyday experience: "The disappearance of a mass of millions of Jews from trade and intermediate trade remains doubtless the central psychoeconomic fact of the occupation period.... Summed up, the economic-

119. Długoborski, "Deutsche Besatzungspolitik," 341.

120. Wyka recorded his keen analysis of society in the GG towards the end of the war near Kraków. Kazimierz Wyka, Życie na niby: Pamiętnik po klęsce, 2d ed. (Kraków, 1984), 157. Wyka's critical observations of behavior patterns in the Polish population were later ignored by specialists in contemporary history.

121. Borwicz, Organizotvanie wściektości, 30.

122. Lukas, Forgotten Holocaust, 127.

123. "Wartości moralne - fundamentem przyszłości," Agencja Prasowa, no. 43, 28 October 1942; quoted in Pawel Szapiro, epilogue to Calel Perechodnik, Czy ja jestem morderca? ed. Pawel Szapiro (Warsaw, 1993), 246.

124. Zygmunt Klukowski, Dziennik z lat okupacji Zamojszczyzny, 1939-1944 (Lublin, 1958), 255; see also the shortened English edition:Diaries from the Years of Occupation, 1939 44, ed. Andrew Klukowski and Helen Klukowski May (Urbana, 1993); Jan Tomasz Gross, "War as Revolution," in Norman Naimark and Leonid Gibianskii, eds., The Establishment of Communist Regimes in Eastern Europe, 1944-1949 (Boulder, Colo., 1997), 26-30.

125. See the small ads in the official Polish language newspapers; see also Ewa Cytowska, Szkice z dziejów prasy pod okupacja niemiecka (1939-1945) (Warsaw, 1986), 117-18.

126. Wyka, Życie na niby, 152. 
cum-moral standpoint of the average Pole towards the Jewish tragedy appears as follows: the Germans, who murdered the Jews, have committed a crime. We would not have done this. The Germans will be punished for this crime, ... but we-we are benefiting [from the new circumstances] and will be benefiting in the future without troubling our conscience or getting blood on our hands." 127

Many peasants likewise enriched themselves at Jews' expense after the authorities had invited them to do so. A report from a village in the GG where the Germans had murdered the Jewish population says that the villagers attacked those who had fled to the surrounding forests, robbed them, and finally denounced them to the German police who shot all of them. ${ }^{128}$ The Catholic resistance group Front for the Renaissance of Poland (Front Odrodzenia Polski, FOP) anxiously remarked in 1942: "The problem of demoralization and running wild caused in the Polish population has become an urgent one. It is not only the [Lithuanian] siaulisi, Volksdeutsche, or Ukrainians who are used for atrocious executions. In many villages (Kolno, Stawiski, Szumów, Dęblin), the local population has voluntarily participated in the massacres." ${ }^{129}$ Poles often embraced Nazi propaganda. Moses Chersztein, who had fled from a Nazi "ghetto" and lived in the Wilno/Vilnius area as a Karaite, has written that in Lipniszki he had "a lot of troubles" because the villagers considered him guilty for the outbreak of a typhus epidemic. ${ }^{130}$ Numerous Jewish eyewitness accounts from occupied Poland report on incidents that give proof to the fact that large segments of the rural population tried to profit from the plight of the Jews - or otherwise get rid of them. ${ }^{131}$

\section{Victims as Collaborators? - The Roman Catholic Church}

As to the Roman Catholic Church in Poland, the Nazi occupiers tried to achieve two main goals: it was to be deprived of its role as sponsor and keeper of Polish patriotic feelings, and the clergy was to be won over to influencing believers in accordance with a stabilization of German rule. Once more (as indicated above), policies in the annexed territories and the GG differed. In the latter, the anti-Catholic measures were less farreaching. Some cloisters were liquidated and church property partly dis-

127. Ibid., 155, 157.

128. Cf. Wladysław Bartoszewski, "75 lat XX wieku: Pamiętnik mówiony," part 6, Wigz 40, no. 7 (July 1997): 111-21, esp. 116.

129. "Proroctwa sie wypełniaja," Prawda, no. 5, May 1942.

130. Cf. M[oses] Chersztein, Geopfertes Volk: Der Untergang des polnischen Judentums (Stuttgart, 1946), 33. After his flight from the Wilno "ghetto" the author called himself Mieczysław Cherszteiński (ibid., 26). The Karaites are a small religious community split off from the main stream of Judaism. They were exempted from the Nazi occupying regime's aim to murder all the Jews.

131. See for example Alicia A. Appleman-Jurman, Alicia: My Siory (New York, 1988), passim; Felicia B. Hyatt, Close Calls: Memoirs of a Survivor (Washington, D.C., 1991), 226; Zofia S. Kubar, Double Identity: A Memoir (New York, 1989), 166-67; report of Noemi SzacWajnkranc in Viktor Mika, Im Fener vergangen: Tagebuicher aus dem Ghetto (Berlin, 1958), 49192; Michael Zylberberg, A Warsaw Diary, 1939-1945 (London, 1969), 201-2. 
possessed. Inscriptions, paintings, plaques, and so on referring to Polish national traditions had to be eliminated from the church interiors, and some hymns and phrases were banned.

On the other hand, the occupation regime tolerated a certain independence of the Catholic Church. In spite of an almost total ban on the Polish press, some papers edited by the dioceses were able to appear as well as, in 1940, the Catholic newspaper Rycerz Niepokalanej (Knight of the Immaculate) ${ }^{132}$ Religious education was allowed to continue in the GG's schools, whereas it was abolished in the other occupied Polish territories. ${ }^{133}$

Against this backdrop one should probably not dismiss as pure cynicism the conviction expressed in Hans Frank's entourage that "the general governor is a great friend of the Polish clergy: he is in Poland the actual protector of the Catholic religion." Hans Frank thought it important to establish that there was "complete consent ... between the Polish clergy and myself." ${ }^{34}$ From time to time, he was also eager to outwardly demonstrate this image, visiting, for example, the national shrine of Polish Catholicism on Jasna Góra in Częstochowa. ${ }^{135}$ Frank expressly reserved for himself the right to decide matters of religion. In particular, he decided in spring 1940, after leaders of the Catholic hierarchy had repeatedly remonstrated with him, to leave religious instruction at the prewar level. ${ }^{336}$

In Polish historiography one encounters the opinion that the clergy did not fulfill the authorities' expectations that they contribute to maintaining order in the GG. 137 "Out of unknown motives," as Czesław Łuczak states, a few priests were ready to partake in Nazi propaganda campaigns

132. Among them, in the Kielce diocese of Bishop Czeslaw Kaczmarek, the Kielecki Przeglad Diecezjalny (from 1939 to January 1943) and, in the Sandomierz diocese of bishop Jan Lorek, the Kronika Diecezji Sandomierskiej. See Marian Paulewicz, "Diecezja kielecka," in Zygmunt Zieliński, ed., Życie religijne w Polsce pod okupacja hillerowska 1939-1945 (Warsaw, 1982 [1983]), 234-52, esp. 242-43.

133. Zygmunt Zieliński, "Das religiöse Leben im besetzten Polen 1939-1945: Ergebnisse eines Lubliner Symposions von 1979," Zeitschrift für Ostforschung 31, no. 1 (1982): 5975 , esp. 71.

134. Curzio Malaparte [pseudonym of the Italian writer and journalist Kurt Erich Suckert], Kaputt (Karlsruhe, 1951), 248-49; see also Edmund Osmańczyk, "Katolicyzm Hansa Franka," Tygodnik Pozuszechny, no. 5 (46), 3 February 1946.

135. Malaparte, Kaputt, 249-57.

136. Eugeniusz C. Król, "Sprawa podręczników szkolnych i pomocy naukowych w jawnym szkolnictwie polskim w Generalnej Guberni w latach okupacji hitlerowskiej," Przeglad Historyczno-Ośzviatouy, 1977, no. 4:395n11.

137. Since the diocesan archives have for a long time remained closed to researchers, this view, to the present day, cannot be considered to have been intensively proven. Some Catholic works actually tell us more about the time of their origin than about their object of research; and because of their biased statements on scant and/or shaky source material, their worth is rather to be established in terms of propaganda. See Libionka's criticism of Dzieto mitosierdzia chrześcijańskiego: Polskie duchowieñstwo a Żydzi w latach okupacï hitlerowskiej (Warsaw, 1969): Libionka, "Kirche in Polen," 195-96. There are similar tendencies in, for example, Andrzej Zapart, "Diecezja sandomierska," in Zieliński, Życie religijne w Polsce, $440-$ 48 , esp. 444. 
by, for instance, exhorting their community to hand over stocks of natural produce. ${ }^{138}$ But by their moderate attitude and mitigating sociopolitical activity, the overwhelming majority of the Catholic clergy in the GG stabilized the situation to a degree that is not to be underestimated. ${ }^{139}$ Like teachers and civil servants, priests had to take notice of the occupiers' official announcements and were also obliged to read aloud their decrees from the pulpit (including the anti-Jewish ones). ${ }^{140}$ In the annexed western part of Poland, about one-tenth of the priests had themselves registered as ethnic Germans. ${ }^{141}$

The attitude of the church hierarchy towards the occupying regime was not uniform. The aged and experienced archbishop of Kraków, Adam Sapieha, was the only noteworthy Polish opponent of the General Governor and was held in high repute among the Poles. Other members of the hierarchy were subject to a rapid diminution in their prestige. The Polish primate Cardinal August Hlond had left the country all too quickly at the beginning of the war. ${ }^{142}$ One patriotic activist was given the impression that some of Poland's religious dignitaries "more or less played into the hands of the Germans or were coming closer to them." As is mentioned in the same contemporary report, many believers "felt hurt by certain measures of the bishops of Sandomierz, Kielce, and Częstochowa because they needlessly accommodated the German authorities." ${ }^{143}$ Some of the dignitaries appealed to their flock to volunteer for work in the Reich. The bishop of Sandomierz, Jan Lorek, recommended, in an announcement from the spring of 1940, that the clergy "give their parishioners instructions in accordance with publications of the [German] employment offices," and he asked them "to keep up contact with those of their flock who go to seasonal work [in Germany] and that they shall require them to be parsimonious, to uphold their faith and good morals in the foreign lands." ${ }^{144}$ At the end of 1942, the underground newspaper of the peasants' movement, Przez walke do zuyciestwa, criticized Lorek's unpatriotic attitude: "Recently, policy has obviously commanded Bishop Lorek of San-

138. Czesław Łuczak, Polityka ludnościowa i ekonomiczna hitlerowskich Niemiec w okupowanej Polsce (Poznañ, 1979), 344.

139. Dhugoborski, "Deutsche Besatzungspolitik," 346.

140. Marek Jan Chodakiewicz, Żydzi $i$ Polacy 1918-1955: Wspótistnienie-zagtadakomunizm (Warsaw, 2000), 192.

141. Zieliński, "Religiöse Leben im besetzten Polen," 65. The author establishes this magnitude on the basis of contributions to a scientific conference held in November 1979 in Lublin. See also the author's introduction to the published results: "Religia w narodowosocjalistycznej koncepcji społeczeństwa," in Zieliński, Życie religijne w Polsce, 11-37, esp. 31 .

142. On 19 September 1939 , the writer Zofia Nałkowska was outraged and noted in her diary "the most malicious hostile propaganda could not invent anything worse: Cardinal Hlond prays in Rome for Poland." Zofia Nałkowska, Dzienniki 1939-1944, ed. Hanna Kirchner (Warsaw, 1996), 75.

143. Kazimierz Gorzkowski, Kroniki Andrzeja: Zapiski z podziemia 1939-1941, ed. Tomasz Szarota (Warsaw, 1989), 123 (January 1941).

144. Quoted in Lucjan Dobroszycki, Die legale polnische Presse im Generalgouvernement, 1939-1945 (Munich, 1977), 82; see also the English edition: Reptile Journalism: The Official Polish-Language Press under the Nazis, 1939-1945 (New Haven, 1994). 
domierz to appeal to believers of his diocese to obey the occupier and register for work in the Reich." 145

Bishop Czesław Kaczmarek of Kielce, who was widely known for his anticommunist views, in September 1939 expressly commanded the faithful to abide by the laws of the occupation regime. In a pastoral letter he appealed "to all of you to conscientiously heed all the instructions and laws issued by the administrative as well as the military authorities. ... Order must rule in society. That is why one has to loyally cooperate with the authorities; because those who act otherwise would do their society an injustice [and] make more difficult a return to normal life and to better days." 146 In spring 1940 Kaczmarek even admonished: "We must not lend our ear to insinuations of suspicious people who try to draw our population-above all our youth - into unpredictable conspiratorial activities. In accordance with their commitments, the German authorities have left us freedom in church and religious life. Do not allow this freedom to be taken from us or restricted owing to rash behavior or any kind of political manifestation." ${ }^{147}$ An announcement of the bishop of Sandomierz from April 1940 made similar points. ${ }^{148}$ In the early years of the occupation, Kaczmarek also personally refused to join conspiratorial activities against the German occupiers. ${ }^{149}$

Hlond had come to the fore in the 1930s with ambivalent statements on the "Jewish question" while warning of the "radically anti-Jewish ethical standpoint imported from abroad that is not compatible with Catholic ethics." From October 1940 to April 1943 he sojourned in exile in France, from whence he tried to inform the west on the situation in Poland. As regards the murder of the Jews, though, he kept silent. Apart from interventions in favor of so-called Jewish Christians, the Roman Catholic hierarchy officially did not meddle in Nazi "Jewish policy." 150

145. "To nie jest w porządku," Przez walke do zuyciesttwa, no. 27, 10 November 1942.

146. Quoted in Dobroszycki, Legale polnische Presse im Generalgouvernement, 81.

147. Ibid., 82. In 1953, as part of a Stalinist campaign against the Catholic Church, Kaczmarek was selected for a show trial and had to answer charges of collaboration owing to his pastorals of 1939-40 as well as his subsequent cooperation with the right-wing resistance group NSZ. Jerzy Stępien,, "Biskup Kaczmarek przed stalinowskimi sędziami," in Longin Kaczanowski, Adam Massalski, Daniel Olszewski, and Jerzy Szczepański, eds., Pamiętnik świętokrzyski: Studia z dziejów kultury chrzésijańskiej (Kielce, 1991), 304-28, esp. 316-17. On the other hand, no Polish bishop during the war had gone so far as to announce a crusade against Bolshevism as French Cardinal Beaudrillard had done. Lemberg, "Kollaboration in Europa," 161.

148. See his pastoral of 2 April 1940: "As your shepherd and spiritual father of all members of the diocese, I fervently appeal to you to keep in this situation great calmness and interior balance. Do not listen to rumors and keep away from rash deeds that must expose our country to an even greater misery and must bring an even greater disaster to our tormented people." Quoted in Dobroszycki, Legale polnische Presse im Generalgouvernement, 82.

149. Gorzkowski, Kroniki Andrzeja, 123 (January 1941); Madajczyk, Polityka III Rzeszy, 2: 194. Cf. the uncritical sketch of Paulewicz, "Diecezja kielecka," who stresses the pressure on Kaczmarek on the part of the Nazi security police whilst completely ignoring the aforementioned pastorals.

150. Cf. the apologetic portrayal by Bishop Henryk Muszyński, "Kardynal August Hlond (1926-1948) wobec Żydów," Collectanea Theologica 61, no. 3 (1991): 81-87. 
Emanuel Ringelblum informs us in his diary that during the antiSemitic excesses in Warsaw in March 1940, a Jewish delegation paid a visit to Archbishop Stanisław Gall. Though he expressed outrage at the violence by Polish youth, he did not demand that priests condemn the excesses. ${ }^{151}$ No documents remain showing that Gall intervened with the authorities or appealed directly to the faithful. In the spring of 1941, Kaczmarek warned in a pastoral published in Kielecki Przeglad Diecezjalny of Jewish children's corrupting influence on Polish Catholic ones. ${ }^{152}$ In the small town of Nur near Biała Podlaska, a priest named Zarzecki told listeners (according to a Soviet NKVD report of October 1939): "Poland's downfall has been brought about by the machinations of the Jews, and I will not die before I have myself shot down fifty Jews." He justified his stance by explaining that he himself experienced how, in September 1939 when the Red Army was about to move into Wilno/Vilnius, the Jews "after the withdrawal of the Polish troops had shot from all sides." 153

A report submitted by church authorities to the Polish government in London in summer 1941, just before the Nazi German administration was about to launch the "final solution of the Jewish question," stated: "As far as the Jewish question is concerned, it must be viewed as a special sign of Divine Providence that the Germans, regardless of the many injustices they have inflicted and continue to inflict upon our country, did well to demonstrate that it is possible to liberate Polish society from the Jewish plague and to show us the path that we should follow unrelentingly, albeit in a less cruel and brutal fashion. It is clearly God's will that the occupiers themselves have contributed to the solution of this burning question, because the Polish nation itself, weak and unsystematic, would never have taken the energetic steps that this matter demands." 154

In 1942-43, the Catholic resistance group Front Odrodzenia Polski was mostly full of praise for the individual stance of clergymen and nuns in view of the persecution of the Jews. It proudly listed the places where the Germans had killed clerics who had tried to hide and rescue victims of persecution. The underground group's monthly Prawda (Truth), however, in July 1942 also mentioned a priest in the Sandomierz diocese who had advised peasants to denounce a Jewish woman who had fled from the "ghetto" in order to seek shelter in the village. The policemen then shot her "like a dog." According to Prawda, this priest was guilty of murder, and a commentary saw in his action "a dreadful confusion of concepts, a per-

151. Szarota, $U$ progu Zagtady, 77, referring to Emanuel Ringelblum's Kronika getta warszawskiego: Wrzesień 1939-slyczeń 1943 (Warsaw, 1983).

152. Dariusz Libionka, "Duchowieństwo diecezji łomżyńskiej wobec antysemityzmu i zagłady Żydów," in Paweł Machcewicz and Krzysztof Persak, eds., Wokót Jedruabnego, vol. 1, Studia (Warsaw, 2002), 105-28, esp. 108.

153. Marek Wierzbicki, "Stosunki polsko-żydowskie na Zachodniej Białorusi w latach 1939-1941," in Machcewicz and Persak, Wokót Jedwabnego, 154.

154. "Sprawozdanie kościelne z Polski za czerwiec i połowę lipca 1941" (Archiwum Studium Polski Podziemnej w Londynie); quoted in Feliks Tych, "Polish Society's Attitudes toward the Holocaust," in Beate Kosmala and Feliks Tych, eds., Facing the Nazi Genocide: Non-Jerus and Jews in Europe (Berlin, 2004), 94-95. 
meation of German ideas to the Polish psyche." 155 Though some parish priests indeed gave help to the persecuted, ${ }^{156}$ there were also clergymen schooled in the spirit of Stanislaw Trzeciak and Ignacy Charszewski, priests profusely active in anti-Semitic publishing, and some even subservient to the Nazi German persecutors' goals. ${ }^{157}$

In the GG the murder of the Jews was carried out with a measure of cruelty that the non-Jewish population could not help noticing in everyday life. The support of a number of Poles in the process of eliminating their Jewish neighbors does not seem to have elicited moral indignation in the manner demanded by Front Odrodzenia Polski. On the contrary, many a report hints at the fact that the participation of Poles in anti-Jewish operations was fairly well known in wider circles of the Polish population - and that a great number (maybe the majority) accepted this.

It has to be stressed that the clergy made little effort to enlighten rural dwellers wont to regard Nazi destruction of Jewish communities as punishment for the crucifixion of Christ and a lack of religiousness among them. ${ }^{158}$ In their sermons the Catholic hierarchy in the GG did not find words to denounce the murder of the Jews. Like most of their compatriots they adhered to anti-Jewish views which had contributed to poisoning Polish-Jewish relations in the 1930s. ${ }^{159}$

In the second half of the occupation period, the authorities made efforts to win church support for a propaganda campaign against the Soviet Union. But at this time they did not succeed in stimulating sermons supporting German rule; ${ }^{160}$ only a few priests joined the campaign. ${ }^{161}$

The communist regime established in 1944-45 was not interested in casting light on the forms of cooperation established between the Roman

155. "Prẹgierz: Nie wolno przemilczać," Prawda, no. 7, 1942. See also Bartoszewski, "75 lat XX wieku," 116.

156. These Polish priests resisted the unlawful Nazi regime by christening Jews, equipping them with false birth certificates, or even hiding them. Libionka, "Duchowieństwo diecezji łomżyńskiej”; Stopniak, "Katolickie duchowieństwo"; Norman Salsitz, A Jeurish Boyhood in Poland: Remembering Kolbuszowa (Syracuse, 1992), 293-95.

157. Lukas, Forgotten Holocaust, 112. As regards Trzeciak and Charszewski, see my review essay on research literature dealing with forms of anti-Semitism in Poland in the 1930s in Aschkenas 7, no. 2 (1997): 557, 561.

158. See Alina Cala, "Wizerunek Żyda w polskiej kulturze ludowej," in Ewa Grześkowiak-Puczyk, ed., Polska, Polacy, mniejszości narodowe (Wroclaw, 1992), 215-23.

159. For the backdrop of Catholic anti-Semitism see Viktoria Pollmann, Untermieter im christlichen Haus: Die Kirche und die "jüdische Frage" in Polen anhand der Bistumspresse der Metropolie Krakau 1926-1939 (Wiesbaden, 2001); Ute Caumanns and Matthias Niendorf, "Von Kolbe bis Kielce: Ein Heiliger, seine Presse und die Geschichte eines Pogroms," in Hans-Jürgen Bömelburg and Beate Eschment, "Der Fremde im Dorf": Überlegungen zum Eigenen und zum Fremden in der Geschichte (Lüneburg, 1998), 169-94.

160. Lukas, Forgotten Holocaust, 115.

161. Among them Anton Krawczyk sive Kraft. See Rafał Habielski, ed., "Radiostacja 'Wanda': Relacja Wladyslawa Kaweckiego," Dzieje Najnowsze 21, no. 1 (1989): 167-225; and "Zdrajcy z niemieckiej radiostacji 'Wanda,' Dziennik Polski i Dziennik Żotnierza, no. 115, 17 May 1945. See also "Niemiecka propaganda przeciwbolszewicka," Biuletyn Informacyjny, no. 10 (217), 9 March 1944, informing about a public meeting in the cinema Apollo in Lublin in which a certain priest Rusek participated with a long lecture. 
Catholic Church in Poland and the German occupier. The new rulers preferred to make use of a religiously tolerant image. Lacking support in the overwhelming majority of Polish society, the communists had to abstainfor the time being - from alienating the Roman Catholic Church and their representatives. The deputy director of the justice department, Leon Chajn, complained in his memoirs that the "authoritative state organs and security organs" refused to investigate after incriminating material "against some of the dignitaries of the church hierarchy" had been collected. The decision was justified by reasoning that "it was not the right time." 162 In any case, this did not restrain the communists from making political capital out of the reproach that certain dignitaries had cooperated too closely with the Germans. In the early postwar aftermath, such initiatives were restricted to the field of propaganda. ${ }^{163}$ In 1944 the press organ of the new regime even opened its pages to the vicar-general of the Lublin diocese, Dr. Józef Kruszyński, and he reported on Nazi crimes against the intelligentsia and the shooting of hostages (but left aside the persecution of the Jews). ${ }^{164}$ One and a half years earlier Kruszyński, formerly head of Lublin's Catholic University, had been criticized in the Home Army underground press for publishing an anticommunist article for the local Polish language daily of the Nazi occupying regime. ${ }^{165}$

\section{Victims as Collaborators?-The Polish Peasantry}

Research in Polish social history during Nazi occupation concentrates largely on the urban population and extrapolates from the broadly shared support for anti-Nazi resistance in the cities. Cities are placed at the center of a mythologized historical narrative. The intense desire of Varsovians to overturn Nazi rule has been described in great detail. More careful consideration shows, however, that such attitudes were anything but typical. ${ }^{166}$

Several factors account for the conspicuous divergence in the attitude towards resistance in the Polish cities - and above all Warsaw- and the country. Peasants figured among those who were alienated and exposed to relative impoverishment in the Second Republic, though they were the most numerous social stratum in a mostly agrarian country. Thus it was not astonishing that in September 1939 the Wehrmacht met with a rather

162. Leon Chajn, Kiedy Lublin byt Warszawa (Warsaw, 1964), 135.

163. See "Kiedy 'Gazeta Ludowa' dba o takt ..., ," an attack on Bishop Lorek in Gtos Ludu, no. 136, 18 May 1946.

164. "Ks. dr J. Kruszyński: Zbrodnia . . Początek rządów niemieckich w Lublinie," Rzeczpospolita, no. 105, 18 November 1944.

165. "Niewybaczalna uleglość," Biuletyn Informacyjny, no. 13 (168), 1 April 1943. Kruszyński's contribution had been headed "Stanowisko duchowieństwa wobec komunizmu." The Home Army's most influential newspaper actually had no objections to Kruszyński's reasoning - only to where it was published: "One can and has to fight communism. But not hand in hand with the Germans, our deadly enemy no. 1." Emphasis in the original.

166. One has to bear in mind that resistance in big cities could take advantage of the anonymity of urban life, whereas the rural population was subject to more rigid social controls. 
low degree of hostility among the rural population. In February and March 1940, more than eighty thousand mostly rural workers from the Generalgouvernement even volunteered for work in the Reich. ${ }^{167}$ In the countryside, the authorities entrusted the provision of the natural produce to the local Polish administration. ${ }^{168}$ As Jan Gross has recently pointed out, statements of Polish eyewitnesses describing the joyful reception of Wehrmacht troops by the Polish population in the areas formerly occupied by the Red Army had to be deleted from a volume of documents edited in the 1960s. ${ }^{169}$

Economically, the peasants belonged to the relative winners of the occupation period because they were able to pass on their losses to consumers by raising food prices on the black market. ${ }^{170}$ Meanwhile, the social and economic development in town and country, where "rising incomes" were to be noted, became more similar: peasants "thus improved their living standard." 171 One Warsaw observer described the situation in the country as follows: "In Poland, the village was the only living and working space where one could preserve one's possessions - and was even able to augment them without getting into conflict with one's civic conscience.... The war's troubles afflicted it only sporadically... The village lived and worked quietly and undisturbed.... These were boom times for the sale of rural products, all of which fetched high prices in the towns, above all in Warsaw and its Jewish ghetto. As a result, country dwellers earned a wealth that was unprecedented." 172

Due to a change in the price structure, which caused a considerable influx of money and products from the town, the early years of occupation were advantageous for farmers' material situation. ${ }^{173}$ Consequently, in the countryside there prevailed a less hostile climate towards the German occupiers. In the end, however, economic well-being depended on one's capacity to take advantage of the double-tracked economy. Hiding

167. The bulk of the so-called Fremdarbeiter, who were later on recruited by force and displaced against their will in order to serve as cheap labor force in the Reich, worked for the Germans only under compulsion. By July 1940, 312,000 Polish workers were transported from the GG to the Reich; in 1941 the number amounted to 200,000. The first ordinance explicitly arranging a compulsory deportation of Poles able to work into Reich territory appeared in the GG no earlier than May 1942. Broszat, Nationalsozialistische Polenpolitik, 103, 106. Towards the end of the war, more than 10 percent of the GG's population had been carried off to the Reich. Dlugoborski, "Deutsche Besatzungspolitik," 334. See also Józef Kasperek, "Niektóre aspekty werbunku na przymusowe roboty do III Rzeszy z dystryktu lubelskiego," in Pilichowski, Zbrodnie i sprawcy, 419-34.

168. Friedrich, "Zusammenarbeit und Mittäterschaft," 122-26; Kazimierz Przybysz, Chtopi polscy wobec okupacji hitlerowskiej 1939-1945: Zachowania i postauy polityczne na terenach Generalnego Gubernatorstwa (Warsaw, 1983), 63-64.

169. Gross, Neighbors, $244 n 3$ in the chapter entitled "Collaboration."

170. Wyka, Życie na niby, 166.

171. Długoborski, “Deutsche Besatzungspolitik," 343.

172. Ferdynand Goetel, Czasy Wojny (London, 1955), 66.

173. See Czesław Rajca, Walka o chleb, 1939-1944: Eksploatacja rolnictwa w Generalnym Gubernatorstwie (Lublin, 1991), 109, 201; Przybysz, Chtopi polscy, 51, 60; Stanislaw Meducki, Wieś kielecka w czasie okupacji niemieckiej (1939-1945): Studium historyczno-gospodarcze (Kielce, 1991), 334. 
agricultural produce, cheating the occupying authorities while feigning loyalty and obedience to their decrees, could all be passed off as patriotic deeds. The ambivalence of such a combination of patriotically moral and economic motives is expressed by the fact that activists of the underground rebuked those who fulfilled the authorities' orders too zealously. They considered peasants hoping to build economic prosperity on good conduct in their dealings with the occupiers "traitors to the peasants' and the nation's cause." 174 Yet to charge a price on the black market that was several times higher than the official one was in keeping with one's personal interests. ${ }^{175}$

The German invaders, who were contemptuous of the Polish peasants, had a genuine interest in developing agriculture in the occupied territories. ${ }^{176}$ Production increased, and Polish and Ukrainian peasants benefited. ${ }^{177}$ As regards the attitude of the peasantry in the first year of occupation, Wyka notes the following statement as typical: "Finally the sun shines also for us. Twenty years have we waited for this change and yet we lived to see it." ${ }^{178}$ Despite a brutal policy of suppression involving the liquidation of old property structures, massacres of civilians, expulsions from the annexed territories, and the persecution of the political elite and the clergy, the mass of the rural population was, as Długoborski states, "up to 1942 comparatively well-off," in any case it did not have "to suffer any losses." ${ }^{179}$ In the territories incorporated into the Reich "the situation of the poor villagers improved considerably compared to the time of Polish rule $[s i c]$. Many of them welcomed the new reign, admired 'German orderliness,' and often openly expressed their thankfulness." 180

The split image of social and economic development is reproduced when we consider how the occupiers enforced their authority in town and country. As to the degree of terror used to deter armed resistance, there was a clear-cut difference between town and country. The victims divide unevenly: 80 percent died in Polish towns (where the overwhelming majority of the Jews had lived), which, according to statistics, lost 45 percent of their population. At the same time, the intelligentsia, that is those who had acquired a higher education, was diminished by one-quarter. On the other hand, the countryside lost 5 percent of its prewar population. ${ }^{181}$ So-

174. Rajca, Walka o chleb, 211.

175. Ibid., 209.

176. See Cytowska, Szkice z dziejów prasy, 104. See also Ewa Cytowska, "Informacje o zyciu i sytuacji spoleczeñstwa polskiego w prasie gadzinowej (1939-1944)," in Mieczysław Adamczyk and Jerzy Jarowiecki, eds., Polska prasa konspiracyjna lat 1939-1945 i poczatki prasy w Polsce Ludowej (Kraków, 1979), 189-93, esp. 191.

177. Przybysz, Chtopi polscy, 54.

178. Wyka, Zycie na niby, 161.

179. Dlugoborski, "Deutsche Besatzungspolitik," 352. Szarota, too, mentions that the population in the towns had to cope with much harsher living conditions. Tomasz Szarota, "Polen unter deutscher Besatzung, 1939-1941: Vergleichende Betrachtungen," in Bernd Wegner, ed., Zwei Wege nach Moskau: Vom Hitler-Stalin-Paki bis zum "Unternehmen Barbarossa" (Munich, 1991), 40-55, esp. 50 .

180. Dlugoborski, "Deutsche Besatzungspolitik," 305.

181. Ibid., 352. 
called pacifications directed against Polish partisan activity saw the following death totals in Polish villages: in 1941, 130; in 1942, 540; in 1943, 2,800; and in 1944 (when a large part of the GG was already under Soviet control), more than 200 Poles. ${ }^{182}$ The details concerning the total number of losses due to the large-scale acts of terror and intimidation against the rural population vacillate between fifteen and twenty thousand. ${ }^{183}$

Stanisław Meducki thinks it was a great success for the Germans to transfer to the Poles responsibility for dividing and collecting the GG's natural produce. ${ }^{184}$ More than forty thousand people were active in the Polish cooperatives, which flourished due to the elimination of the Jews from economic life. According to Długoborski, there was no shortage of "employees who knew how to take advantage of their positions to enrich themselves to the detriment of Polish society": "subservient zeal and corruption" were widespread, "especially with the functionaries in the country." 185 Czesław Szczepańczyk comes to the conclusion that the cooperatives carried out the policies of the Nazi regime (just like the railway and the post office administration) and have to be considered a part of it. ${ }^{186}$ In order to influence farmers' behavior in accordance with their aims, the occupiers made use of commendations, bonuses, and intensive propaganda that rivaled that of the Polish resistance groups. Whereas the latter appealed to the farmers to keep back their compulsory deliveries of natural produce as long as possible and to hand in less and in lesser quality than was due, the Germans pressured them with the slogan: "Peasant, by delivering your contingent of natural produce you will help to nourish your brothers." 187 As it seems, such efforts did not miss their target; as Wyka concedes, the occupier's policy "dimmed the farmers' clear view." 188

As Długoborski explains, only in the later occupation period, when it became difficult to meet compulsory deliveries, did the cooperatives' employees get into an "especially awkward position." ${ }^{89}$ According to Czeslaw

182. Ibid., 320 .

183. Przybysz states that there occurred "765 large-scale terrorist and repressive operations (in each of them at least ten persons were murdered)," which took the lives of 19,792 people. Przybysz, Chtopi polscy, 71. See also Józef Marszałek, "Bilanse II wojny światowej," in Zygmunt Mankowski, ed., Druga wojna światowa: Osady, bilanse, refleksje (Lublin, 1996) , 55-69, esp. 64. Compare to this the desolate situation in Warsaw wherebefore the 1944 uprising - thirty thousand inhabitants had become victims of executions; whereas in the beginning of 1942 there were more than 1.4 million inhabitants, after the destruction of the Jewish quarter and the systematic destructive action during and after the Jewish and the Polish uprising, there were, in January 1945, only 162,000 left. Barbara Krajewska, "Ludność Warszawy w latach 1939-1945," in Studia Warszawskie, vol. 17, Warszawa lat wojny i okupagii, 1939-1944, no. 3 (Warsaw, 1973), 185-207, esp. 199, 207.

184. Meducki, Wieś kielecka w czasie okupacji niemieckiej, 335.

185. Długoborski, "Deutsche Besatzungspolitik," 324, 346. See also Gross, Polish Society under German Occupation, 143-44.

186. Czeslaw Szczepańczyk, Polityka okupanta wobec spótdzielczości wiejskiej w Generalnej Guberni: 1939-1944 (Warsaw, 1978), 259.

187. Nowy Gtos Lubelski, July 1943; quoted in Cytowska, Szkice z dziejów prasy, 101.

188. Wyka considers the factory workers, too, as an unreliable element in Polish society. Wyka, Życie na niby, 131

189. Długoborski, "Deutsche Besatzungspolitik," 360. See also Friedrich, "Zusammenarbeit und Mittāterschaft," 122-26. 
Rajca, "Terror and repression including the death penalty" were applied against those farmers who attempted to benefit from the growing difference between official and black-market prices and eluded their duty to deliver produce to the occupying regime. ${ }^{190}$ Such indiscriminate and excessive terror caused peasants, as the writer Ferdynand Goetel opines, to "progress very well as regards their patriotic feelings." ${ }^{191}$

\section{Conclusion}

In the reality of the occupation, the behavior of those willing to cooperate rarely fits today's black-and-white standards. As Długoborski points out, "According to widespread feelings in society, the boundary between personal enrichment and treason against one's nation . . . was fluid." 192 During the occupation period, hardly anyone was purely a collaborator or a resistance fighter. ${ }^{193}$ Everyday life under the occupation frequently called for compromising. But little attention is paid to the fact that collaboration and resistance mingled, or that civil servants made a commitment to both sides. Bohdan Skaradziński speaks aptly of several cases of "kolaboracja dwustronna" - a two-fold collaboration - on the part of Polish policemen. The reason for this was to secure oneself against the vicissitudes of the war's concluding days. ${ }^{194}$

The Polish and the Jewish fate under the Nazi regime have often been equated in Poland. As to the work duty for Poles and the compulsion to work for Jews, Czesław Madajczyk states that the differences between the two "in practice got blurred." ${ }^{95}$ He forgets, however, that young Polish men in the Baudienst participated in the murder of Jews as helpers of the SS and German police. Czesław Rajca suggests that under the German occupation half a million people died of hunger because this was intended by Nazi agricultural policy in the GG. He in turn fails to note that the loss was indeed a consequence of the occupiers' calculations in terms of a radical "population policy." The excessive number of Jews and Soviet prisoners-of-war who died from hunger has to be put down to a Nazi racist hierarchy in which they were assigned a lower position than the Poles. Kazimierz Wyka, the chronicler of life in the GG, had already forgotten the murdered Jews when he described the rebellious mood in Warsaw just before the beginning of the Polish uprising: "The city never did take heed of defeat and occupation." 196 The author writes this at a time when Warsaw's Jews, before the war one-third of the city's inhabitants, had been almost completely eliminated by the Germans and their helpers.

190. Czeslaw Rajca, "Eksploatacja rolnictwa w Generalnym Gubernatorstwie w propagandzie niemieckiej," in Zbigniew Kwaśny, ed., Badania z dziejów spotecznych i gospodarczych (Wroclaw, 1987), 58.

191. Goetel, Czasy wojny, 68.

192. Długoborski, "Deutsche Besatzungspolitik," 321.

193. Maybe because of this, Lukas treats them both in one and the same chapter:

"Civilian Resistance and Collaboration." Lukas, Forgotten Holocaust, 95-120.

194. Skaradziński, "W czasach wojny," no. 1:98.

195. Madajczyk, Polityka III Rzeszy, $1: 639$.

196. Wyka, Zycie na niby, 107. 
Estimates of the number of Polish collaborators vary from seven thousand ${ }^{197}$ to about one million. ${ }^{198}$ Those willing and ready to fight the German occupier possibly made up one-quarter of the population. The bulk of the Poles cooperated and collaborated with the Germans as much as survival in the abnormal life of occupation required or allowed. In view of the persecution of the Jews, most of them adopted a policy of wait-andsee. This passivity did not keep some from profiting from the plight of their Jewish competitors. Wyka thought that "The manner in which the Germans liquidated the Jews becomes a burden on their conscience. How we [Poles] reacted to this is a thing we have to sort out for ourselves." 199 In the eyes of the Jewish population, these Polish reactions almost inevitably had to appear as silent approval of the occupiers' actions.

A difficult problem for an impartial approach to these issues is the ostracism of any kind of cooperation with the Germans that gained acceptance after the war. Following 1944-45 it became almost impossible to speak out for the advantages of a moderate way of behaving, since this was considered unpatriotic by the overwhelming majority then entangled in nationalistic (if not chauvinistic) rhetoric. The only outstanding counterexample I have come across to this day is a courageous statement by the great Polish liberal writer and satirist Stefan Kisielewski, who, in 1947, sang a most noteworthy hymn of praise to the Czech response to aggression:

... the Czechs. I always esteemed this clever, sober, self-controlled people that is nevertheless true to itself and rises from every defeat. ... In our country the Czech is indeed not popular at all. ... There are situations when it is easier and simpler to fight, [but] more difficult and painful to abstain from fighting. During the occupation, an acquaintance of mine observed that there should come into being a Polish quisling government ... "After the war we will hang them," he said, "they will be scapegoats, yet in the meantime fewer people will go to Auschwitz-isn't this worth it?" "But then we will be regarded as an ally of the Germans," I said to him. "What harm can it do?" he answered, "it will even be better because after a war the Anglo-Saxons usually esteem their enemies more than their small allies whom they think little of. Besides, they will understand in the end that the Poles could not know in advance who will win the war." There is cynicism in this but also a bit of cleverness. ... Let us try to understand the Czechs, let us learn a lot of things from the Czechs and finally-let us love the Czechs! . . Three cheers for our Czech brothers! [Niech żyją Czesi]. ${ }^{200}$

Since then, sufficient material for a "history of collaboration in Poland" has been amassed in contemporary Polish newspapers and journals, as well as by a number of studies in Poland and abroad, and there is currently no official censor preventing the publication of perhaps unflattering findings. The reason why this material is not used for a novel perspective on occupied Poland-including the Soviet occupation-might be

197. Lukas, Forgotten Holocaust, 117

198. Madajczyk, “'Teufelswerk,'” 146.

199. Wyka, Zycie na niby, 157.

200. Tygodnik Powszechny, no. 17 (110), 4 May 1947. 
found in the role of Polish historiography as the keeper of sometimes mythologized and idealized conceptions of contemporary history that, however, not only historians but large segments of a wider public have become accustomed to. Thus, what is regarded as Polish national selfinterest, it seems, precludes the acceptance of evidence of collaboration.

A glance at the historiography of People's Poland shows that the false idyll of a united Polish nation (or Volksgemeinschaft), resisting the occupiers in complete solidarity, gained acceptance in the end-though under communist auspices. The historians in the People's Republic eventually were fond of picturing, in Jan Gross's words, "the war period as one of heroic struggle by a united society against the 'Hun invasion.'" 201

To this day, Polish mental images of the occupation are to a large extent governed by an intense sense of martyrdom that fixes itself upon ethnic Poles. As a result, a new look at Polish cooperation and collaboration will entail far-reaching consequences. It can hardly be separated any longer from a new and more sophisticated approach towards Polish-Jewish relations under the Nazi occupying regime-and before. Such an avenue should, for example, take account of the fact that there exists a huge discrepancy between the prevalence of żydokomuna- the myth of Jewish Bolshevism -in the Polish popular imagination, and the continuing failure in Polish historiography to reappraise this phenomenon in a scholarly manner.

The number of Jews rescued owing to the help of Poles is still subject to the politics of memory. In Poland it is variously estimated at "some tens of thousands" by Kazimierz Przybysz, or even more than one hundred thousand by Czesław Łuczak. ${ }^{202}$ In reality, at the end of the occupation there were probably no more than ten to fifteen thousand Jews, hidden by Poles, left in the countryside. By contrast, Polish peasants were exceedingly helpful towards Polish compatriots in need, for example after the expulsion of Poles from Warsaw after the uprising of 1944.

A more general reappraisal should lead scholars to undertake an effort to replace the allegedly evenly balanced number of Polish and Jewish victims of the Nazi German rule in Poland with a more reliable estimate. Then it would turn out that the actual number of Polish (Gentile) victims was much lower than the Jewish figure of around three million dead. Necessarily, this process would be accompanied by a thorough revision of much of the pertinent historiographical literature produced since the 1960s, when Polish scholars started to aggressively dispossess the Jewish victims by elaborating the image of the so-called shared suffering of Poles and Jews into the claim that in death centers (extermination camps) the Nazis aimed at killing off the Polish population.

Meanwhile, Polish historians' tendency to shift the blame for collaboration with the German occupiers to the "mob" and the margins of society, to singular cases of "degenerates" and to Poland's minorities-

201. Gross, Polish Society under German Occupation, 139.

202. Przybysz, Chtopi polscy, 227; Łuczak, Polityka ludnościozua, 591. See also the overview by Beate Kosmala, "Ungleiche Opfer in extremer Situation: Die Schwierigkeiten der Solidarität im okkupierten Polen," in Wolfgang Benz and Juliane Wetzel, eds., Solidarität und Hilfe für Juden während der NS-Zeit: Regionalstudien I (Berlin, 1996), 19-98, esp. 91. 
including the ethnic German Poles who since 1939 put their personal good under the occupying regime before their ties to the Polish state and nation-enables them to externalize the phenomenon as if it had nothing to do with "ordinary Poles." Poland's recurring debates on collaboration suggest that this guideline is based on questionable views of Polish national self-interest. Once such mental predispositions are overcome, though, it will be easier for Polish society to come to terms with the past. 